\title{
The Holocene fluvial sedimentary record and alluvial geoarchaeology in the Nile Valley of Northern Sudan
}

Link to publication record in Manchester Research Explorer

\section{Citation for published version (APA):}

Woodward, J. C., Macklin, M. G., Welsby, D. A., Maddy, D. M. (Ed.), \& Mackin, M. G. (Ed.) (2001). The Holocene fluvial sedimentary record and alluvial geoarchaeology in the Nile Valley of Northern Sudan. In River Basin Sediment Systems: Archives of Environmental Change (pp. 327-356). A. A. Balkema.

\section{Published in:}

River Basin Sediment Systems: Archives of Environmental Change

\section{Citing this paper}

Please note that where the full-text provided on Manchester Research Explorer is the Author Accepted Manuscript or Proof version this may differ from the final Published version. If citing, it is advised that you check and use the publisher's definitive version.

\section{General rights}

Copyright and moral rights for the publications made accessible in the Research Explorer are retained by the authors and/or other copyright owners and it is a condition of accessing publications that users recognise and abide by the legal requirements associated with these rights.

\section{Takedown policy}

If you believe that this document breaches copyright please refer to the University of Manchester's Takedown Procedures [http://man.ac.uk/04Y6Bo] or contact uml.scholarlycommunications@manchester.ac.uk providing relevant details, so we can investigate your claim.

\section{OPEN ACCESS}




\section{RIVER BASIN SEDIMENT SYSTEMS: ARCHIVES OF ENVIRONMENTAL CHANGE}

Edited by Darrel Maddy, Mark G. Macklin \& Jamie C. Woodward

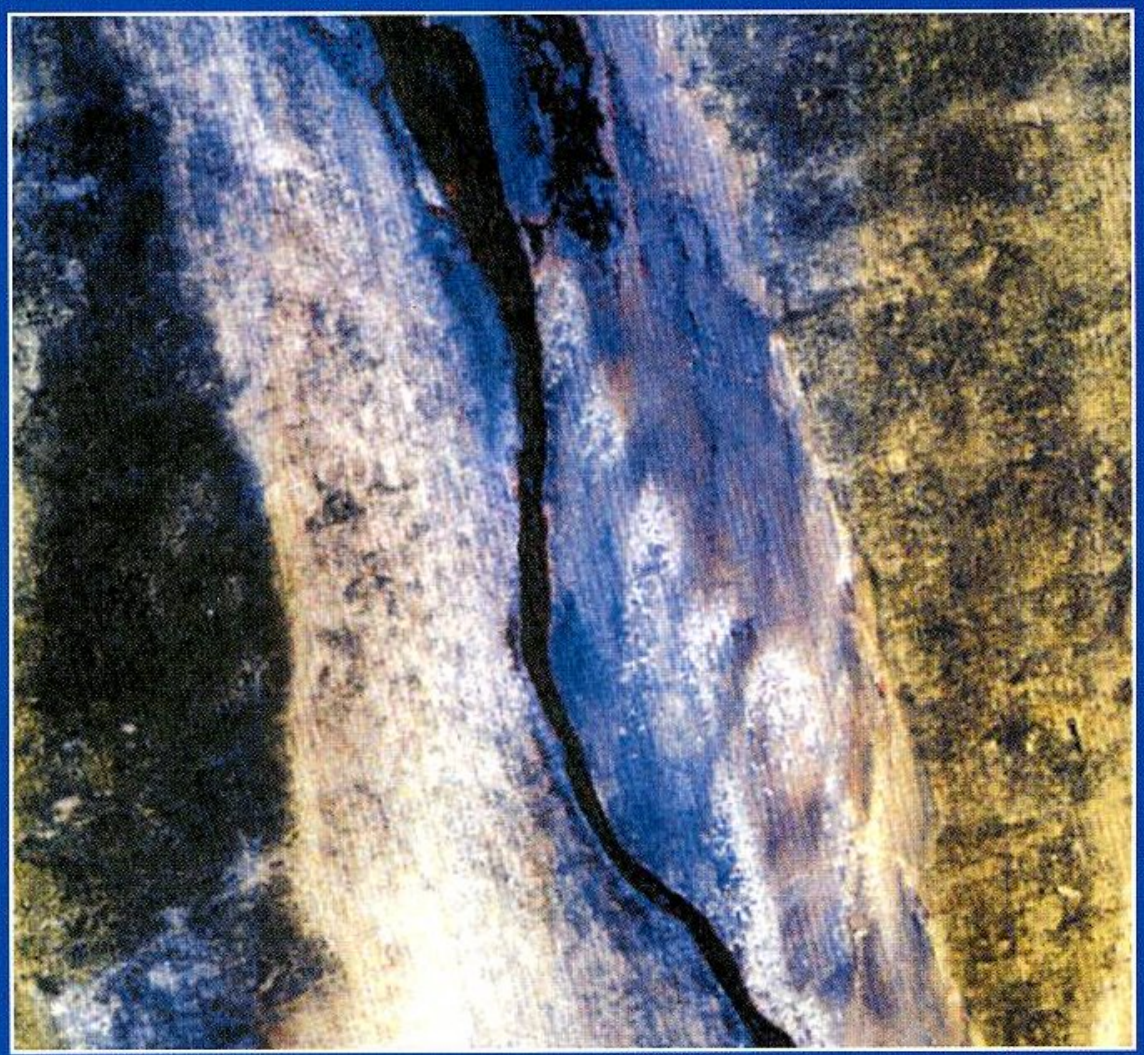




\section{River Basin Sediment}

\section{Systems: Archives}

\section{of Environmental Change}

\section{Edited by}

\section{Darrel Maddy}

Department of Geography, University of Newcastle, Newcastle upon Tyne, UK

\section{Mark G. Macklin}

Institute of Geography and Earth Sciences, University of Wales, Aberystwyth, UK

\section{Jamie C. Woodward}

School of Geography, University of Leeds, UK

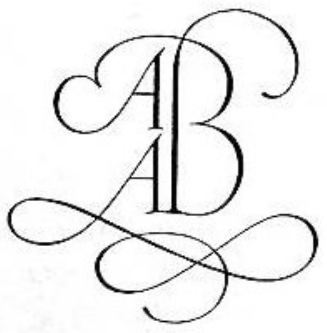

Published by

A.A. Balkema Publishers, a member of Swets \& Zeitlinger Publishers www.balkema.nl and www.szp.swets.nl

\section{(C) 2001 Swets \& Zeitlinger B.V.}

All rights reserved. No part of this publication may be reproduced, stored in a retrieval system, or transmitted in any form or by any means: electronic, mechanical, by photocoping, recording or otherwise, without the prior written permission of the publishers. 


\title{
11. The Holocene fluvial sedimentary record and alluvial geoarchaeology in the Nile Valley of northern Sudan
}

\author{
JAMIE C. WOODWARD \\ School of Geography, University of Leeds, UK \\ MARK G. MACKLIN \\ Institute of Geography and Earth Sciences, University of Wales, Aberystwyth, UK \\ DEREK WELSBY \\ The Sudan Archaeological Research Society, The British Museum, London, UK
}

\section{INTRODUCTION}

It is now well known that Nile basin hydrology is closely linked to the intensity of the African monsoon and large fluctuations in discharge and sediment transfer during the Quaternary Period have been driven by changes in global climate (Williams \& Adamson, 1980; Hassan, 1981; Rossignol-Strick et al., 1982; Hulme, 1994). These changes are recorded in pollen and lake level data from across Africa (e.g. Gasse et al., 1980; Ritchie et al., 1985), and these palaeoclimate records have been integrated to establish the duration and spatial extent of wet and dry phases during the Late Quaternary (Street \& Grove, 1979; Street Perrot et al., 1989; Hassan, 1996). In the headwaters of the Blue and White Niles, marked changes in precipitation and runoff regime have taken place throughout the Quaternary as a result of changes in the Earth's orbit (Milankovitch Cycles), global ocean temperature anomalies, and migrations of the Inter-Tropical Convergence Zone (ITCZ) (Hulme, 1994). As the nature of Late Quaternary fluvial sedimentation and erosion in the Nile Valley downstream of Khartoum is intimately related to the flood hydrology and sediment yield of the major headwater catchments, the vicissitudes of Pleistocene and Holocene climate have produced a varied and complex geomorphological and stratigraphic record in the Saharan Nile (Butzer \& Hansen, 1968; Adamson et al., 1980; Williams \& Adamson, 1982).

Long term fluctuations in Nile basin runoff are also recorded in the Nile Delta. Here, heavy mineral suites in sediment cores signal the changing importance of headwater basin sediment source areas during the Late Pleistocene and Holocene because the Blue and White Niles drain lithologically distinctive terrains (Foucalt \& Stanley, 1989). However, in contrast to the Nile Delta records and these intensively studied areas upstream (Butzer \& Hansen, 1968; Williams \& Adamson, 1982), there is little well-dated geomorphological and stratigraphical information on long-term river behaviour for much of the Sudanese Saharan Nile downstream of Khartoum. In this part of the Nile basin the nature, age and spatial extent of the alluvial sedimentary record is not well known (Butzer, 1980). Furthermore, in many of these reaches, detailed archaeological surveys of the valley floor have not been carried out.

Previous investigations of long-term fluvial processes in the Nile Valley have commonly been hampered by the scarcity of suitable samples for radiocarbon dating and the age of many of the sedimentary sequences is poorly constrained (e.g. Butzer \& Hansen, 1968). Good geochronological control is essential for any attempt to elucidate the nature of Late Pleistocene and Holocene river behaviour and to compare alluvial histories with 
328 Jamie C. Woodward et al.

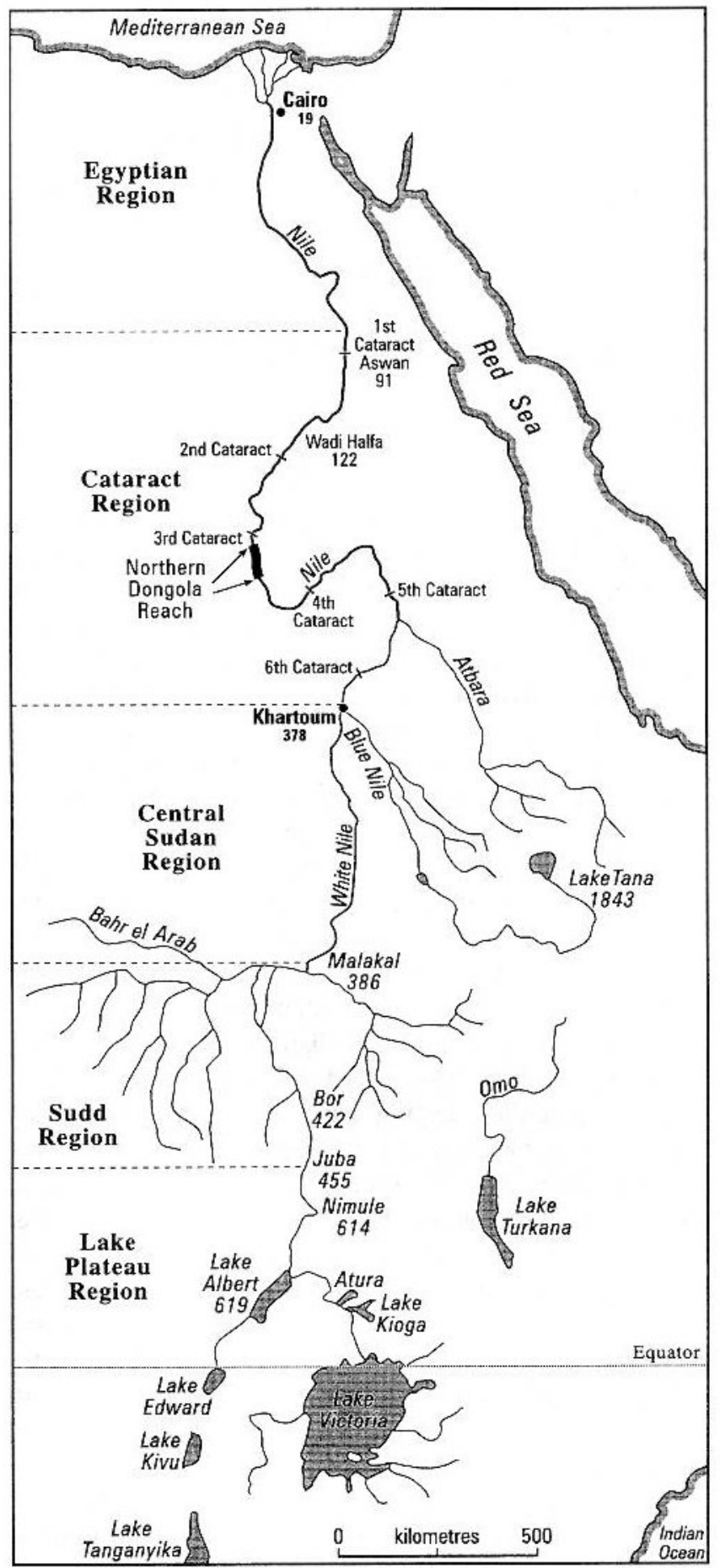

Figure 1. Map of the Nile basin showing the major tributaries and the main locations and sites mentioned in the text (after Said, 1994). 
proxy climate records and archaeological data. This paper reports recent geomorphological research into Holocene river development in the Northern Dongola Reach of Sudanese Nubia (Fig. 1). Optically stimulated luminescence (OSL) dating techniques have been applied to develop a timescale for Holocene river activity in the region. This work was conducted in association with a large-scale archaeological survey of the valley floor by a team from the Sudan Archaeological Research Society (SARS) of the British Museum (Welsby, 1995). The aims and objectives of the archaeological survey and our geomorphological work are outlined below.

\section{ALLUVIAL GEOARCHAEOLOGY AND THE NORTHERN DONGOLA REACH SURVEY}

Variability in the source, seasonality and volume of discharge has exerted a major influence on the nature and distribution of human activity in the Nile corridor. Indeed, flood magnitude and resource availability have exerted a profound influence on the riparian landscapes and peopling of the Nile Valley since Lower Palaeolithic times (Wendorf \& Schild, 1976; Butzer, 1980; Said, 1993). Most research into the impact of Nile flood dynamics on riparian land use and the archaeological record has been focused on the Egyptian Nile Valley (Butzer, 1981; Hassan, 1997). Thus, while many of the prominent archaeological sites in the Sudan - such as Kawa, Meroe and Kerma - have been excavated at various times during the present century (Fig. 2), large sectors of the Sudanese Nile Valley have not yet been systematically surveyed. In addition, many archaeological sites in the Sudanese Nile Valley are currently under threat from agricultural development (Welsby, 1995).

A SARS team has recently completed a detailed archaeological field survey in the Northern Dongola Reach. The survey area includes the well preserved site of Kawa that was first excavated in the 1920s and 1930s (Fig. 2). This site includes a temple built by Tutankhamun around $1350 \mathrm{BC}$ and a large Kushite town (Welsby, 1998). Kawa is probably the most important site surviving in the Sudanese Nile Valley for the study of the period from the 18 th Dynasty to the 4 th century $\mathrm{AD}$ and is currently being surveyed and excavated by a new SARS project (Welsby, 1998). The surrounding area was not surveyed during the early investigations and much of the Northern Dongola Reach remained unexplored prior to the Northern Dongola Reach Survey (NDRS) which began in January 1993.

The NDRS focused on the nature and distribution of archaeological sites from the prehistoric period up to recent times. One particularly striking outcome of this work is the close correspondence between sites dating to the Kerma Period (c. 2500-1500 BC) and the margins of former Nile channel belts, some of which are located more than $15 \mathrm{~km}$ away from the present channel. As this pattern emerged, it became increasingly clear that a full interpretation of the cultural sequence in the Northern Dongola Reach would not be possible without an understanding of the Holocene alluvial record - including the age and mode of formation of the palaeochannel belts in the region. This paper outlines the archaeological survey data and presents the results of geomorphological and stratigraphical work on the Holocene fluvial record in the Northern Dongola Reach. This geoarchaeological work is ongoing and has three broad aims:

1. To conduct a geomorphological and stratigraphical evaluation of Holocene river behaviour in the Northern Dongola Reach. 


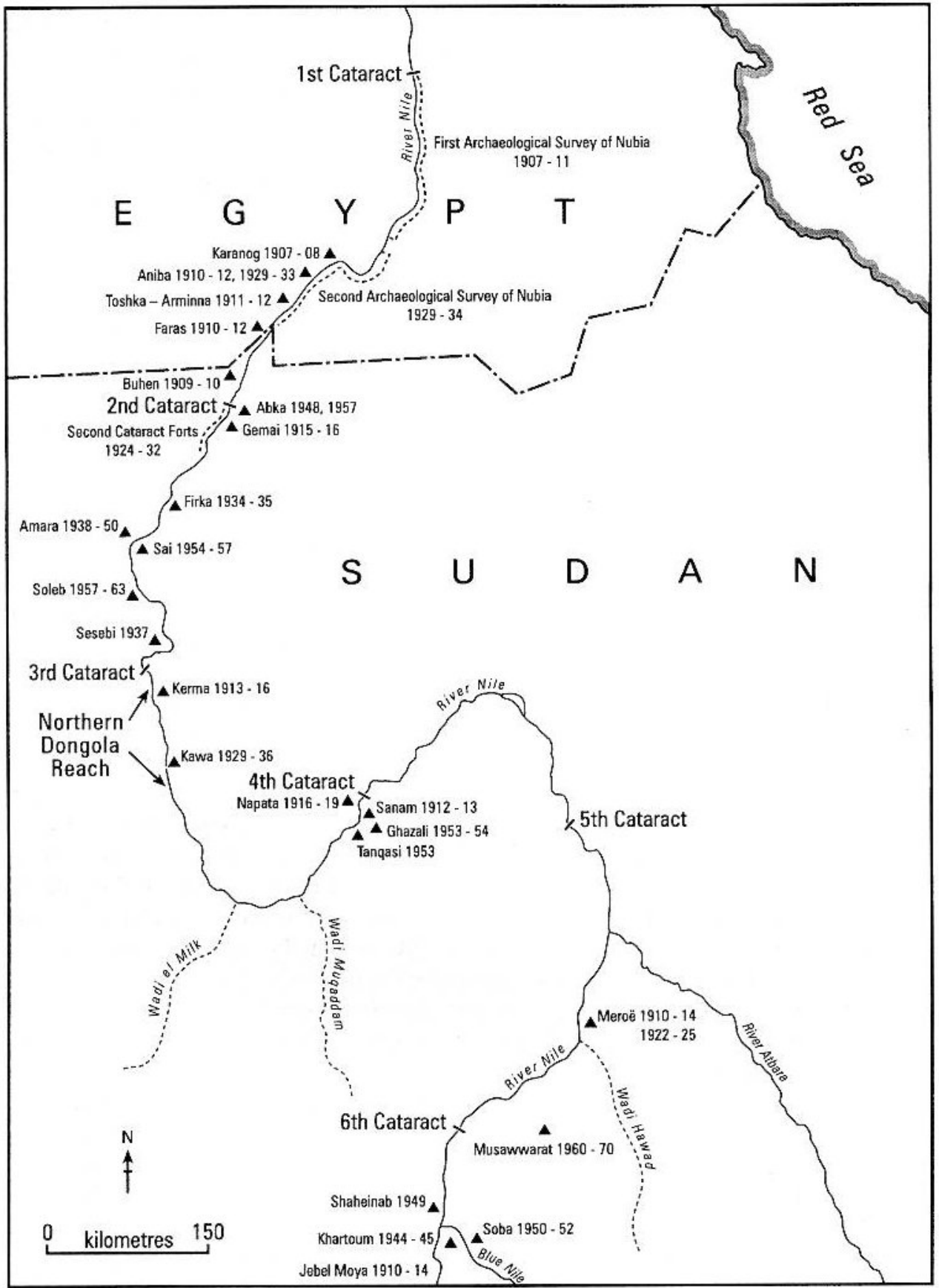

Figure 2. The main archaeological sites in the Sudanese Nile Valley and the Northern Dongola Reach Survey concession. Dates are given for the main phases of survey and excavation at each site (after Adams, 1977). 
2. To establish the age of the alluvial sedimentary sequence and the palaeochannel belts using OSL and radiocarbon dating techniques.

3. To elucidate the temporal and spatial relationship between archaeological sites and the palaeochannel belts and assess the roles of climate change and flooding in long-term river behaviour and riparian land use.

\section{THE NILE BASIN SEDIMENT SYSTEM}

The Nile is the world's longest river (c. $6670 \mathrm{~km}$ ) draining around one tenth of the African continent (Fig. 1). The present average contribution to main channel flows from each of the three main tributary basins of the Blue Nile, White Nile and Atbara is shown in Figure 3. Runoff from the Ethiopian highlands via the Blue Nile and Atbara accounts for roughly $70 \%$ of the annual water discharge and $>95 \%$ of the suspended sediment load emphasising the importance of the East African monsoon (Foucalt \& Stanley, 1989; Hulme, 1994). In contrast, the White Nile contributes less than one third of the discharge and its sediment load is small in comparison to the other two main tributaries - accounting for only $3 \%$ of the total load (Foucalt \& Stanley, 1989). The mean annual suspended sediment load of the modern Nile (upstream of the High Aswan Dam) is estimated to be around 120 million tonnes per year (Milliman \& Syvitski, 1992), but the magnitude of the conveyance losses to the channel and floodplain zone is not known.

The Blue Nile drains the mountains of Ethiopia and produces torrential flows during the summer monsoon (July to October) and very low flows during the dry season. In fact, the ratio of maximum to minimum flows can exceed 20:1 and from July to August, the ratio of the Blue Nile flows to those of the White Nile can be of the order of 97:1 (Andah \& Siccardi, 1991). Thus, the White Nile, which drains the equatorial lakes of the central African plateau, is crucial for maintaining flows in the Saharan Nile from November to June (Figs 1 and 3B). The gauged flood record of the 20th century reveals considerable interdecadal and inter-annual variability in Nile discharge (Evans, 1994). For example, 1916 recorded the maximum annual water yield of 120 billion cubic metres in contrast to the minimum of only 42 billion cubic metres for 1984 (Hulme, 1994).

\section{LATE QUATERNARY HISTORY OF THE NILE}

The dimensions of the Nile catchment have not been constant during the Quaternary, with periodic severing of the White Nile headwaters serving to enhance the seasonality of flows. Until the late Middle Pleistocene, the geomorphological evolution of the Egyptian Nile Valley was strongly influenced by more local runoff with major east bank wadis supplying the bulk of the sediment and water. Butzer (1980) has argued that almost all of the Pleistocene gravel-sand units in Upper Egypt can be attributed to regional runoff from the Red Sea Hills.

The importance of the Blue Nile sediment system has been outlined above and Williams \& Adamson (1980) have proposed a model for the behaviour of this basin during the Last Glacial Maximum and the early Holocene which is illustrated in Figure 4. In very general terms, the Late Quaternary history of the Nile can be summarised as follows: 
332 Jamie C. Woodward et al.

A

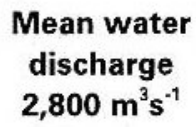

MAIN NILE

$100 \%$

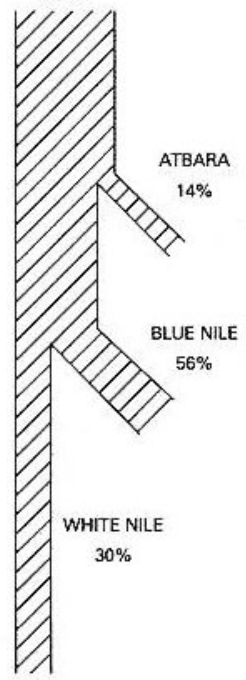

Suspended sediment load $120 \times 10^{6} \mathrm{t} / \mathrm{yr}$

MAIN NILE $100 \%$

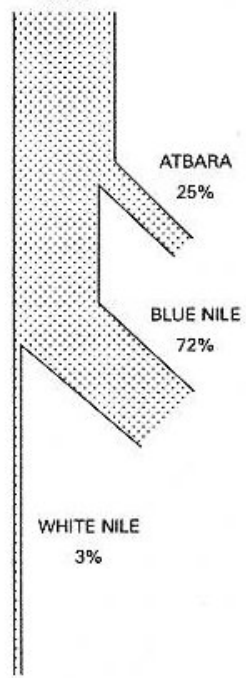

B

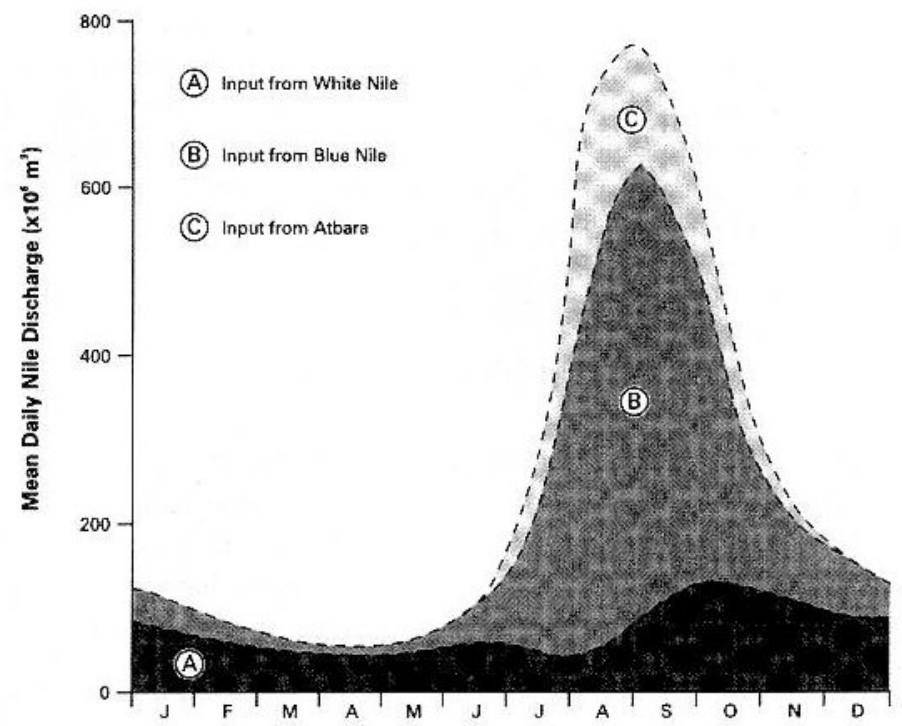

Figure 3. A) The water and suspended sediment budget of the present Nile basin (after Foucalt \& Stanley, 1989). Water yield and sediment load data after UNESCO and Milliman \& Syvitski (1992) respectively. B) The seasonal pattern of discharge of the main Nile and the contributions from the Blue Nile, White Nile and Atbara (after Hurst, 1952). 


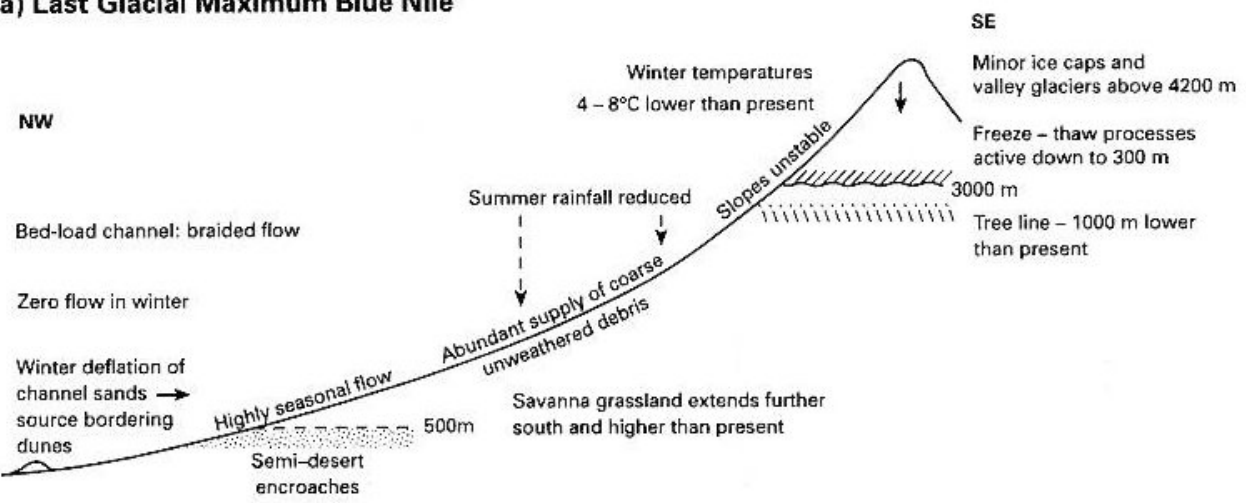

\section{(b) Early Holocene Blue Nile}

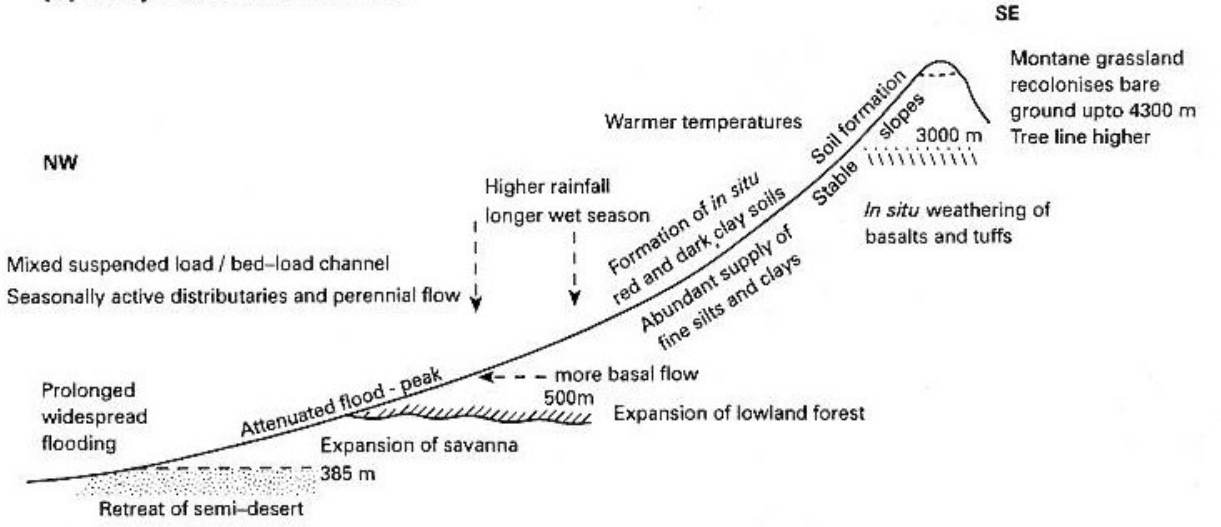

Figure 4. The Blue Nile during: a) The Last Glacial Maximum and b) The early Holocene (after Williams \& Adamson, 1980).

A last glacial dry phase from c. 20 to $12.5 \mathrm{ka} \mathrm{BP}$ associated with cold conditions in the Ethiopian Highlands produced rapid erosion from bare hillslopes as the tree line stood about $1000 \mathrm{~m}$ lower than today. Throughout this period, large volumes of coarse and fine sediments were delivered to the fluvial system and net aggradation took place in many reaches of the main channel downstream (Williams et al., 1998) (Fig. 4). At the global scale, these conditions were produced by the highly reflective ice sheets, the cool oceans, and the equatorward-extended sea-ice borders (which displaced the polar front and midlatitude westerlies towards the equator) and the reduction in the extension and intensity of the African monsoon (Hulme, 1994).

Towards the end of the last cold stage, more humid conditions developed as the increase in summer insolation in the Northern Hemisphere enhanced thermal contrasts between land and ocean and African monsoon intensity increased. Thus, both African lake levels and Nile flows were generally higher between c. 12.5 and $5 \mathrm{ka}$ BP (Street \& Grove, 


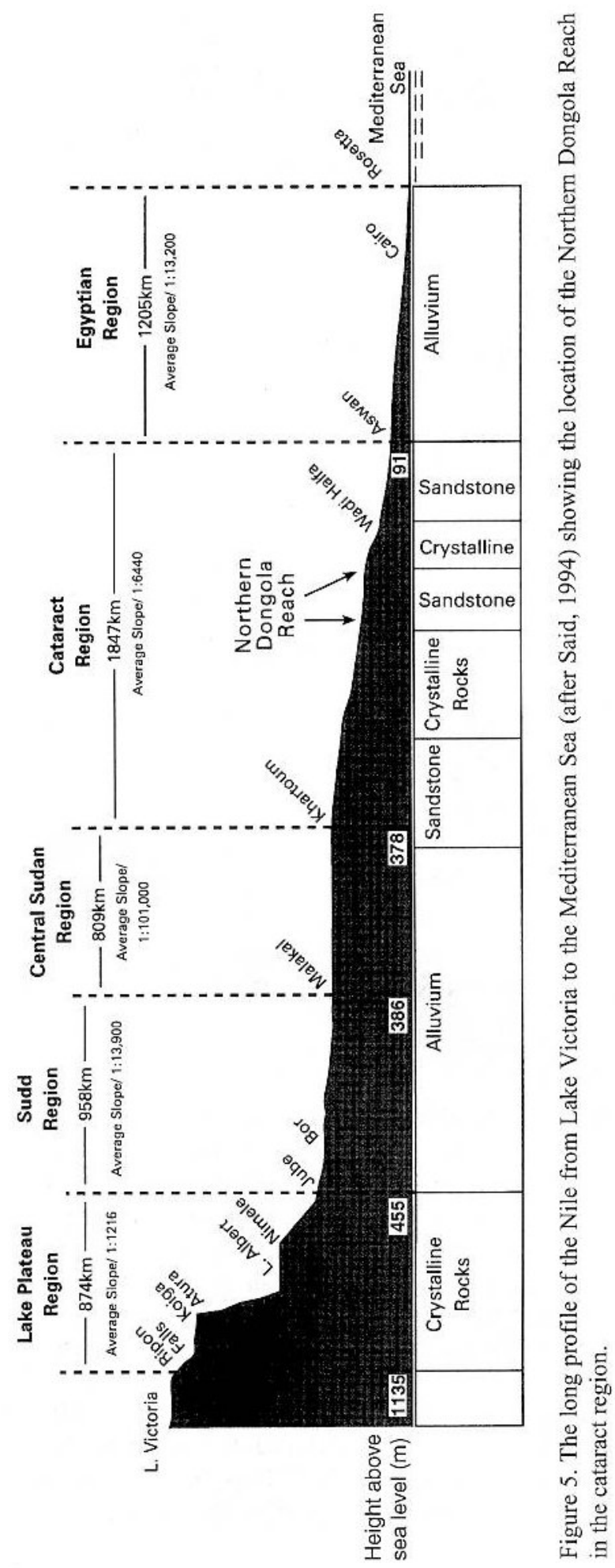


1979; Williams et al., 1998), although this period was punctuated by several short-lived dry periods (Gasse \& van Campo, 1994; Hassan, 1996). The main channel of the Nile shifted from the cold stage, sediment-charged braided system to a predominantly singlechannel as the Ethiopian uplands were stabilised by vegetation and sediment yield declined (Fig. 4). During this early Holocene humid phase the northern front of monsoonal rain extended about $700 \mathrm{~km}$ northward from its present position and recharged groundwater stores, enhanced fluvial runoff and created lakes across the Sahara (Ritchie et al., 1985; Hassan, 1996). In contrast, the last five thousand years or so has been characterised by a progressive increase in aridity (Williams et al., 1998) with no significant runoff inputs downstream of the Atbara (Fig. 1).

\section{THE NORTHERN DONGOLA REACH}

Figure 5 shows the long profile of the Nile from Lake Victoria (1135 $\mathrm{m}$ above sea level) to the Mediterranean Sea. The cataract region of the main Nile Valley lies between Khartoum (378 m a.s.1.) and Aswan (91 m a.s.1.) where the channel falls over $280 \mathrm{~m}$ over a distance of some $1847 \mathrm{~km}$. The Northern Dongola Reach is a relatively low gradient stretch of the Nile Valley which lies upstream of the Third Cataract. The wide alluvial plain of the Dongola Reach extends for a distance of about $313 \mathrm{~km}$ between the Fourth and Third Cataracts and the channel has a low average gradient of $0.083 \mathrm{~m} \mathrm{~km}^{-1}$. This part of the valley is underlain by Nubian Sandstone and the lower part of this stretch includes all of the Northern Dongola Reach where our archaeological and geomorphological investigations have taken place (Figs 1 and 5). Upstream of Dongola the Nile Basin covers an area of some $1,610,000 \mathrm{~km}^{2}$ and has a mean annual water yield of 89 billion cubic metres.

Plate 1 is a SPOT satellite image of the Northern Dongola Reach which shows the palaeochannel belts and the other major geomorphological features in the region. The absence of prominent river terrace features and the low relief of the terrain (excluding the aeolian sand dunes) from the modern Nile to the bedrock plateau in the east, indicates that the alluvial valley floor has filled relatively uniformly in the recent geological past (Fig. 6 and Plate 1). The Dongola Reach is an extensive alluvial basin containing a series of major palaeochannel belts and smaller palaeochannel features where localisation of sedimentation along river channels has created subtle elevation differences between upstanding levées and lower-lying inter-channel areas. Large-scale avulsion may be initiated by floods that breach levées, shift channel position or behead channels through channel incision (Richards et al., 1993).

\section{THE KERMA PERIOD AND ARCHAEOLOGICAL SURVEY IN THE NORTHERN DONGOLA REACH}

\subsection{The Kerma Period}

The Egyptian retreat from Nubia under the Thirteenth Dynasty, late in the 18th century BC, correlates with the rise of a rich culture at Kerma in the most fertile part of Sudanese Nubia (Phillipson, 1993). Kerma is an ancient city on the Nile in central Nubia located approximately $40 \mathrm{~km}$ upstream of the $3 \mathrm{rd}$ cataract region and approximately $55 \mathrm{~km}$ downstream 


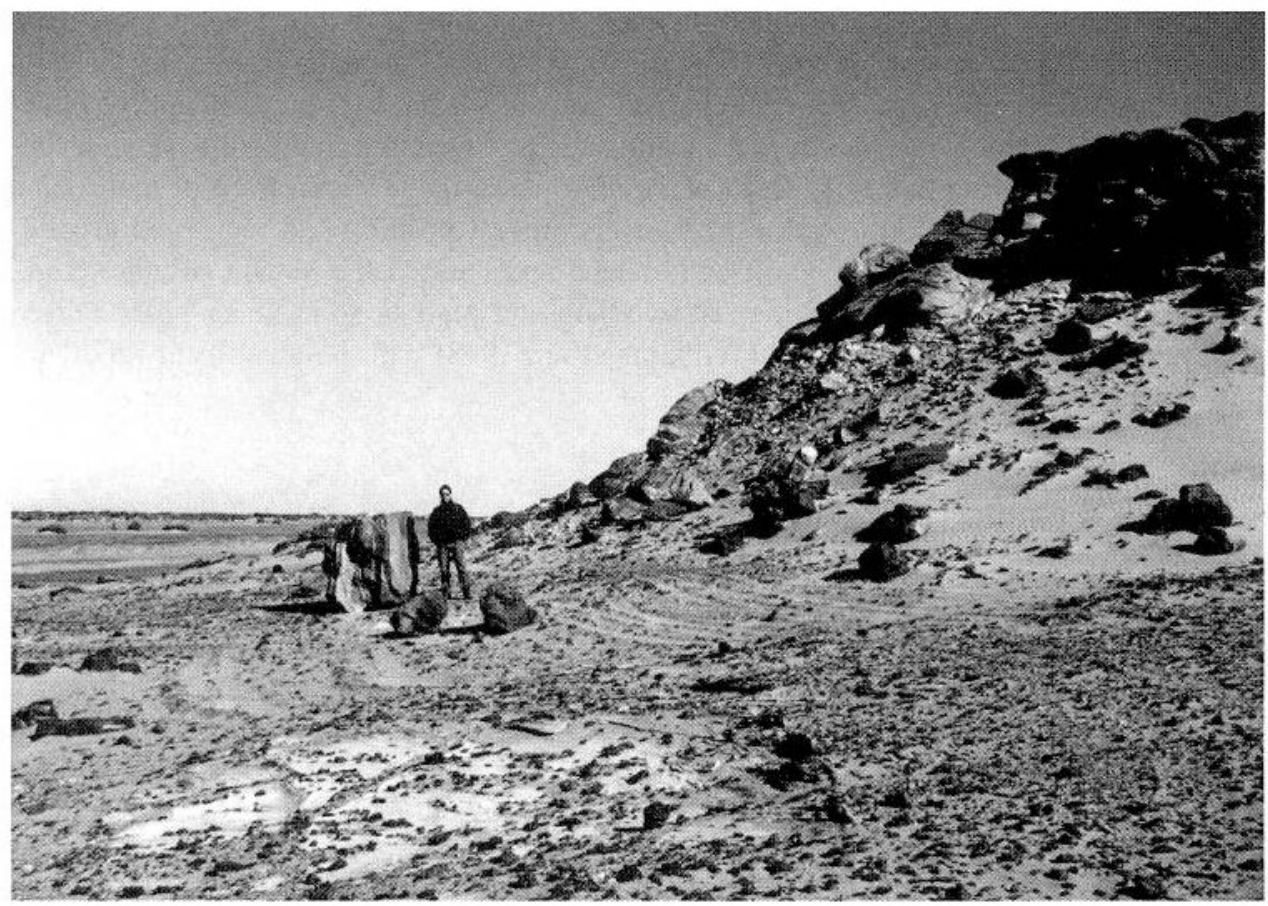

Figure 6. The Nubian Sandstone bedrock plateau which marks the eastern edge of the alluvial valley floor in the Northern Dongola Reach and the eastern margin of the archaeological survey (see SPOT image).

of Kawa (Fig. 2). Kerma was an important strategic location at the southern limit of Egyptian control and commanded an extensive network of trading routes (Bonnet, 1992). The Kerma Period spanned a thousand years from c. 2500 to $1500 \mathrm{BC}$ and great wealth and a remarkable level of craftsmanship - particularly in pottery - were attained. Archaeological research in the Kerma necropolis of Sai (about $100 \mathrm{~km}$ to the north of Kerma) lead to the identification of four phases in the development of the Kerma civilization (see Bonnet, 1992) and these are shown in Table 1. This sub-division is based on several criteria including contrasts in pottery styles, funerary ritual and tomb morphology.

\subsection{The Northern Dongola Reach Survey}

The Sudan Archaeological Research Society held a concession for survey and trial excavation for an area $80 \mathrm{~km}$ north-south by a maximum of $18 \mathrm{~km}$ east-west on the east bank of the Nile (Welsby, 1995). Under the direction of Derek Welsby, the Northern Dongola Reach Survey began in January 1993 and involved systematic field survey along east-west transects at 5 minutes of latitude intervals (approximately $9.25 \mathrm{~km}$ ), and the recording of the more visible sites throughout the survey area (Welsby, 1995). The area was divided into 24 grid squares (each $5^{\prime}$ of latitude by $5^{\prime}$ of longitude) and extended from the modern settlements of Eimani in the north to Mulwad opposite el Khandaq in the south (Fig. 7). The eastern limit of the valley floor is marked by a Nubian sandstone bedrock scarp which lies approximately $10 \mathrm{~m}$ above the valley floor (Fig. 6). 
Table 1. The four chronological periods of the Kerma culture (after Bonnet, 1992) and the earlier and later cultures in the Northern Dongola Reach.

\begin{tabular}{ll}
\hline Period & Dates \\
\hline Neolithic & Before $3500 \mathrm{BC}$ \\
Pre-Kerma & 3500 to $2500 \mathrm{BC}$ \\
Early Kerma & 2500 to $2050 \mathrm{BC}$ \\
Middle Kerma & 2050 to $1750 \mathrm{BC}$ \\
Classic Kerma & 1750 to $1580 \mathrm{BC}$ \\
Final Kerma & 1580 to $1500 \mathrm{BC}$ \\
& \\
New Kingdom & $1500-$ c. $1070 \mathrm{BC}$ \\
Kushite: Napatan & 9 th to 4 th Century BC \\
$\quad$ Meroitic & 4 th Century BC to 4th Century AD \\
Post-Meroitic & 4 th Century AD to 6th Century AD \\
Medieval & 6 th Century AD to 15 th Century AD \\
\hline
\end{tabular}

A four-season survey recorded over 450 new sites and many of these date to the Neolithic and Kerma periods (Fig. 7 and Table 1). Two main palaeochannel belts to the east of the modern Nile were identified during the 1993/1994 season. The eastern palaeochannel belt which runs roughly north-south (traversing grid squares I, M and P, Fig. 7) close to the bedrock scarp was named the Alfreda Nile and this turns westwards to join the central palaeochannel belt (in the southeastern corner of grid square $R$ ) which was named the Hawawiya Nile (Welsby, 1995). Downstream of this confluence zone the palaeochannel belt flows close to the Seleim Basin (Plate 1 and Fig 7) and was named the Seleim Nile by Welsby (1995).

In this part of the Nile Valley the present course of the river is an incised, predominantly single channel system (Plate 1) and is referred to here as the Dongola Nile. Sites dating to the Neolithic and Kerma Periods were found on the margins of the Alfreda, Hawawiya and Seleim palaeochannels and by the Dongola Nile. Neolithic sites are found throughout most of the survey area although they are more dispersed than the Kerma sites and a significant number are not closely associated with the major palaeochannels (Fig. 8). The Neolithic inhabitants utilised large mounds for their burials and such features are often found several kilometres apart - mainly between the Alfreda and Hawawiya palaeochannel belts and well to the east of the Seleim Nile (Welsby, 1995). A particularly important feature of the survey data is the close association of the Kerma sites with the major palaeochannel belts (Fig. 8). The Kerma sites in the Northern Dongola Reach include numerous cemeteries, occupation areas indicated by spreads of pottery, and prominent raised mounds with some isolated buildings (Fig. 9). Apart from Kawa itself, later sites dating to the Pharaonic and Napatan periods were rare or non-existent throughout the survey area (Welsby, 1995). Indeed, all the evidence for Meroitic, Medieval and later settlement (Table 1) was located along the banks of the present course of the Dongola Nile (Welsby, 1995). Elucidating the relationship between river behaviour and riparian settlement and land use during the Kerma and later periods is a particular focus of this project. 


\section{Jamie C. Woodward et al.}

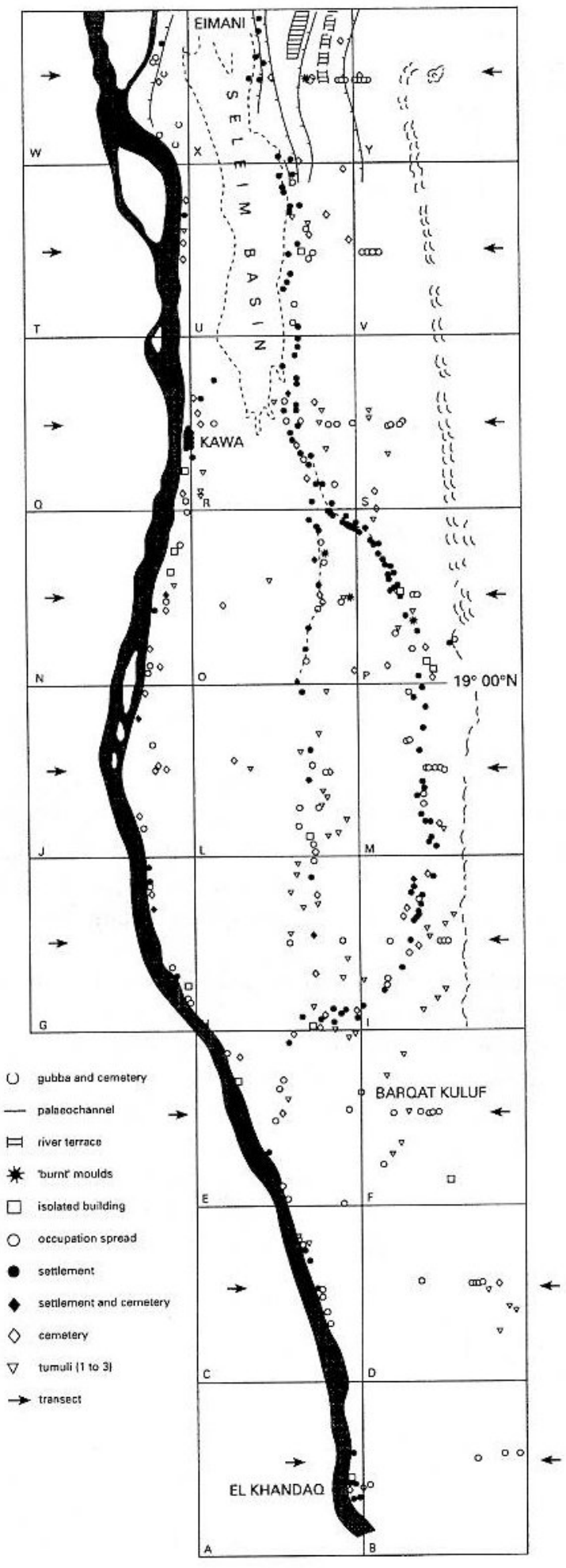

Figure 7. The distribution of archaeological sites of various ages in the Northern Dongola Reach recorded by the British Museum SARS survey (after Welsby, 1995). 

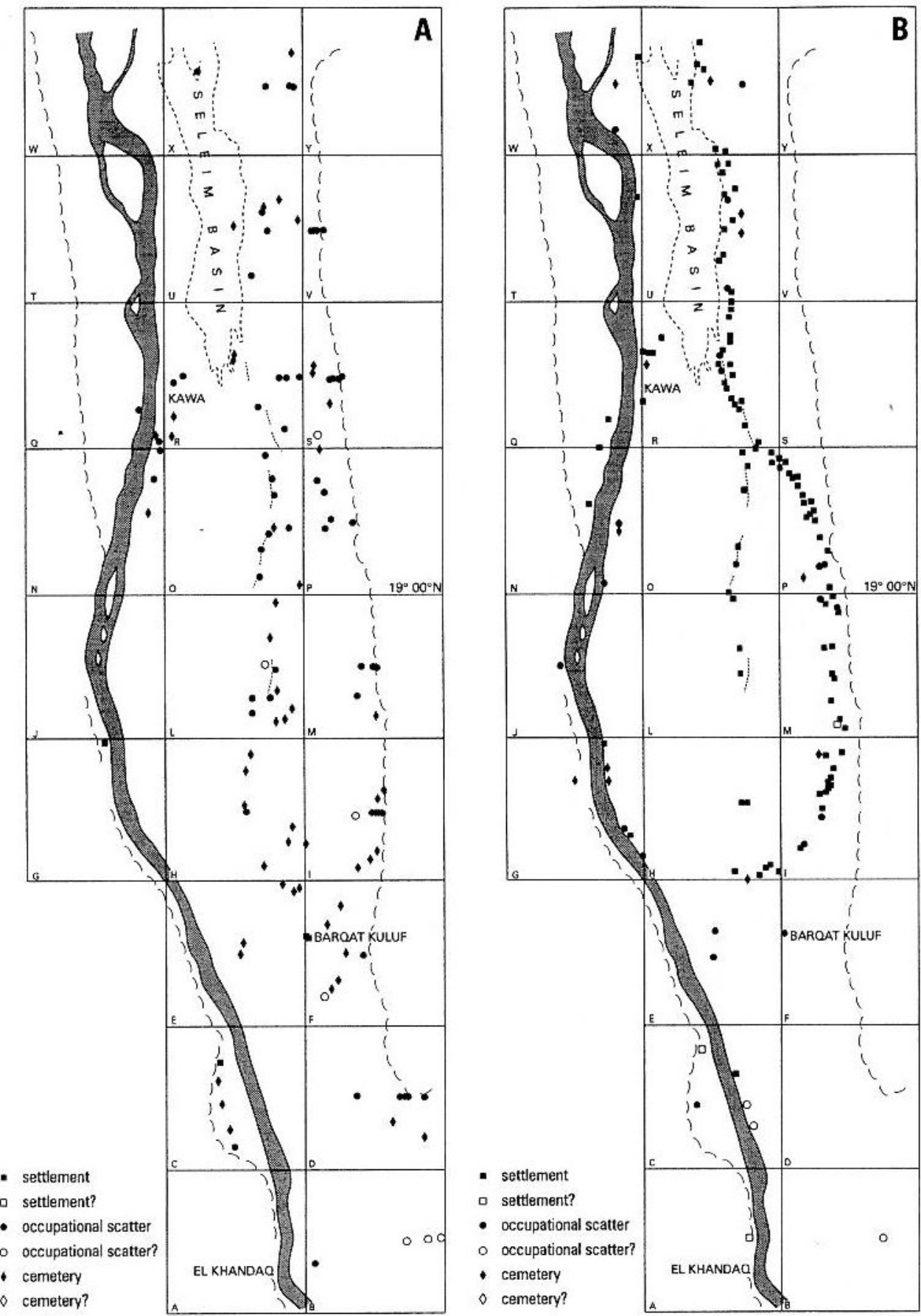

Figure 8a, b. The distribution of archaeological sites of various ages in the in the Northern Dongola Reach Survey. A) Neolithic sites, B) Classic Kerma sites (see Table 1). 


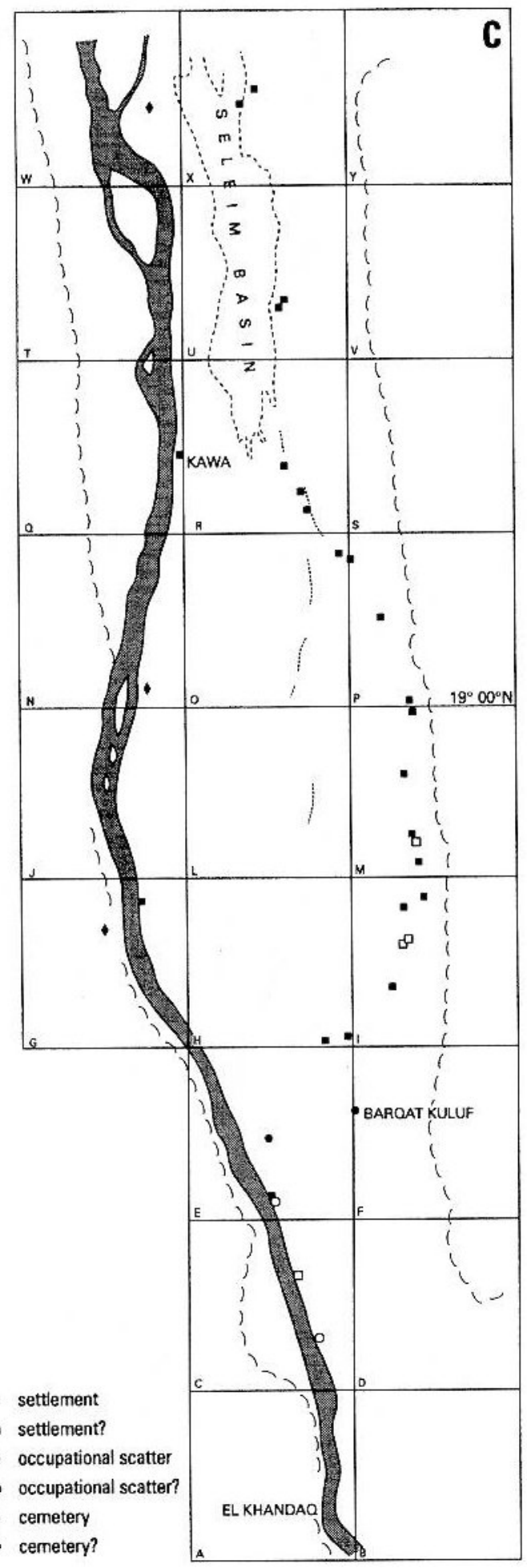

Figure 8c. The distribution of archaeological sites of various ages in the Northern Dongola Reach Survey. C) Sites occupied between the end of the Classic Kerma and the beginning of the Kushite periods (see Table 1). 


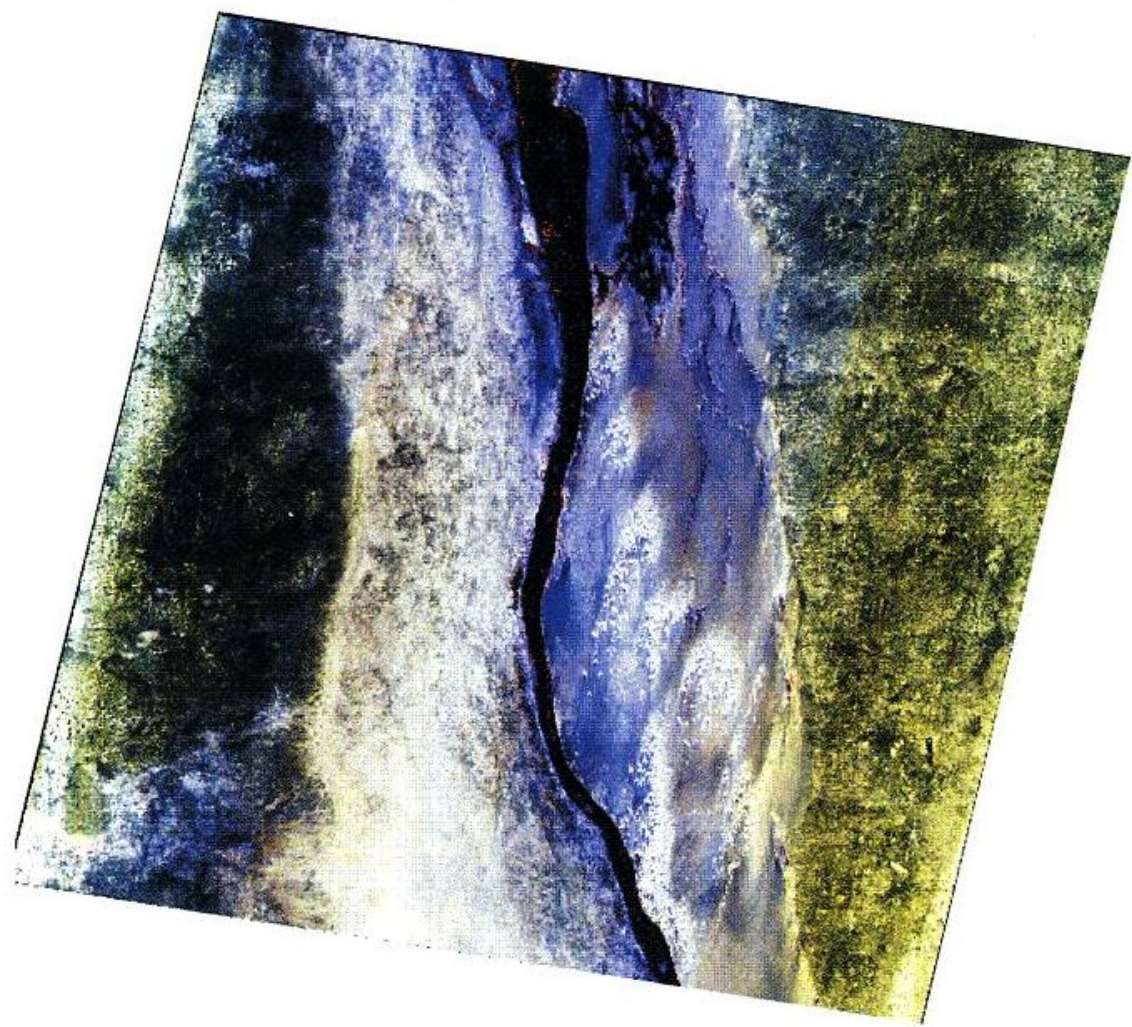

Plate 1. A SPOT satellite image of the Northern Dongola Reach. This image shows the present channel of the Dongola Nile and the archaeological survey area to the east. The bedrock plateau at the eastern margin of the Holocene alluvial valley floor is clearly marked and the major palaeochannel belts can be identified in the upper half of the image. Note the presence of several large aeolian dune fields in the central and western parts of the survey area. The Seleim basin is at the top of this image to the east of the modern Nile (compare to Figure 7). This image covers an area of $60 \mathrm{~km} \times 60 \mathrm{~km}$. 


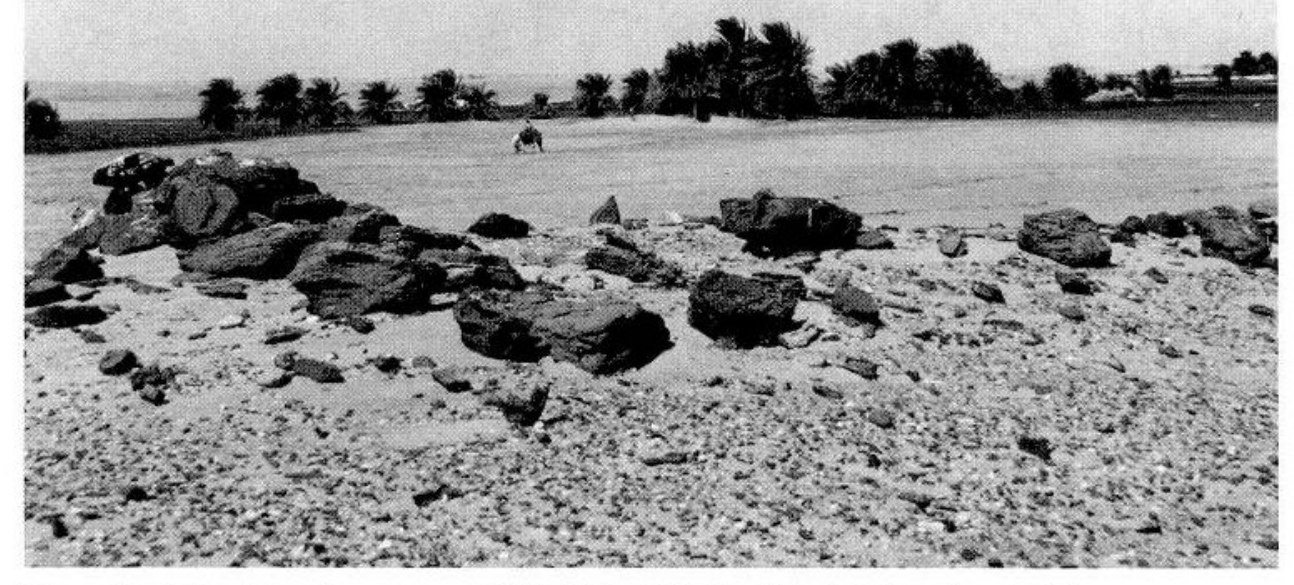

Figure 9a. A Kerma settlement mound (Site P5) within the Alfreda Palaeochannel belt.

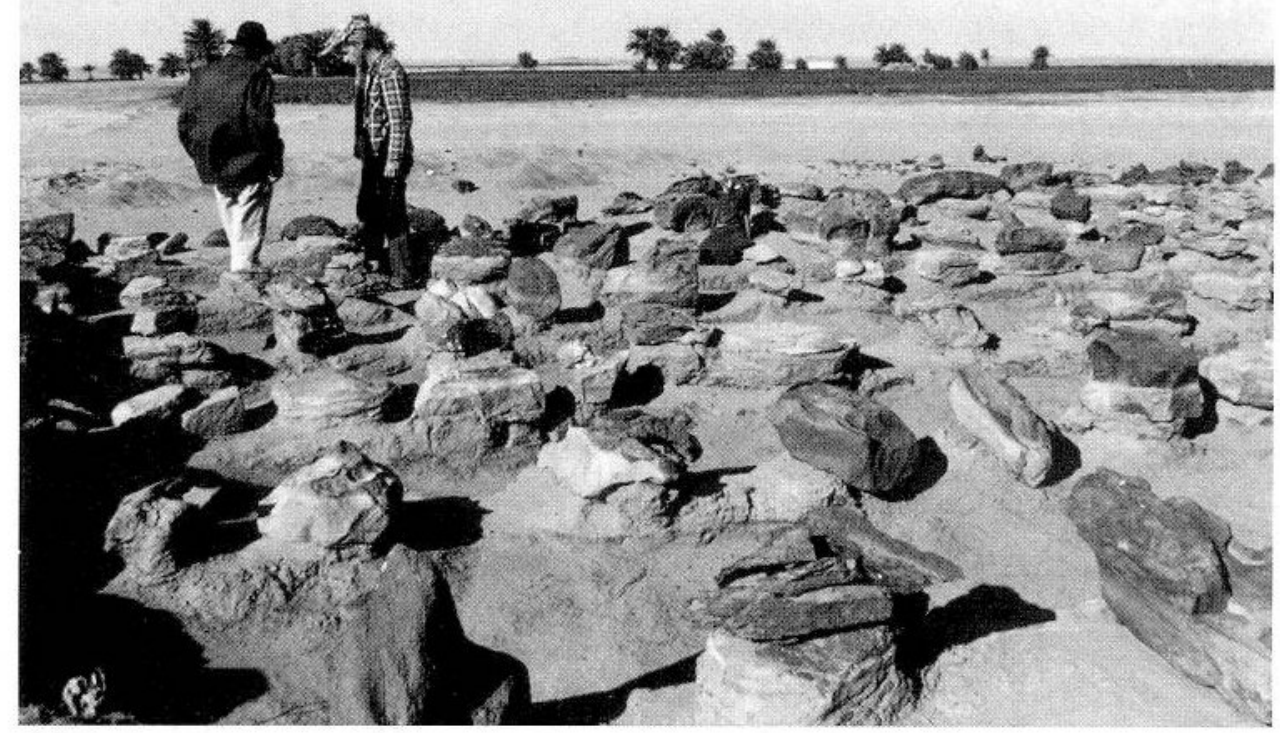

Figure 9b. The Kerma building under excavation at P4 (see Welsby, 1998) close to Pit 14 (see Fig. 11). 


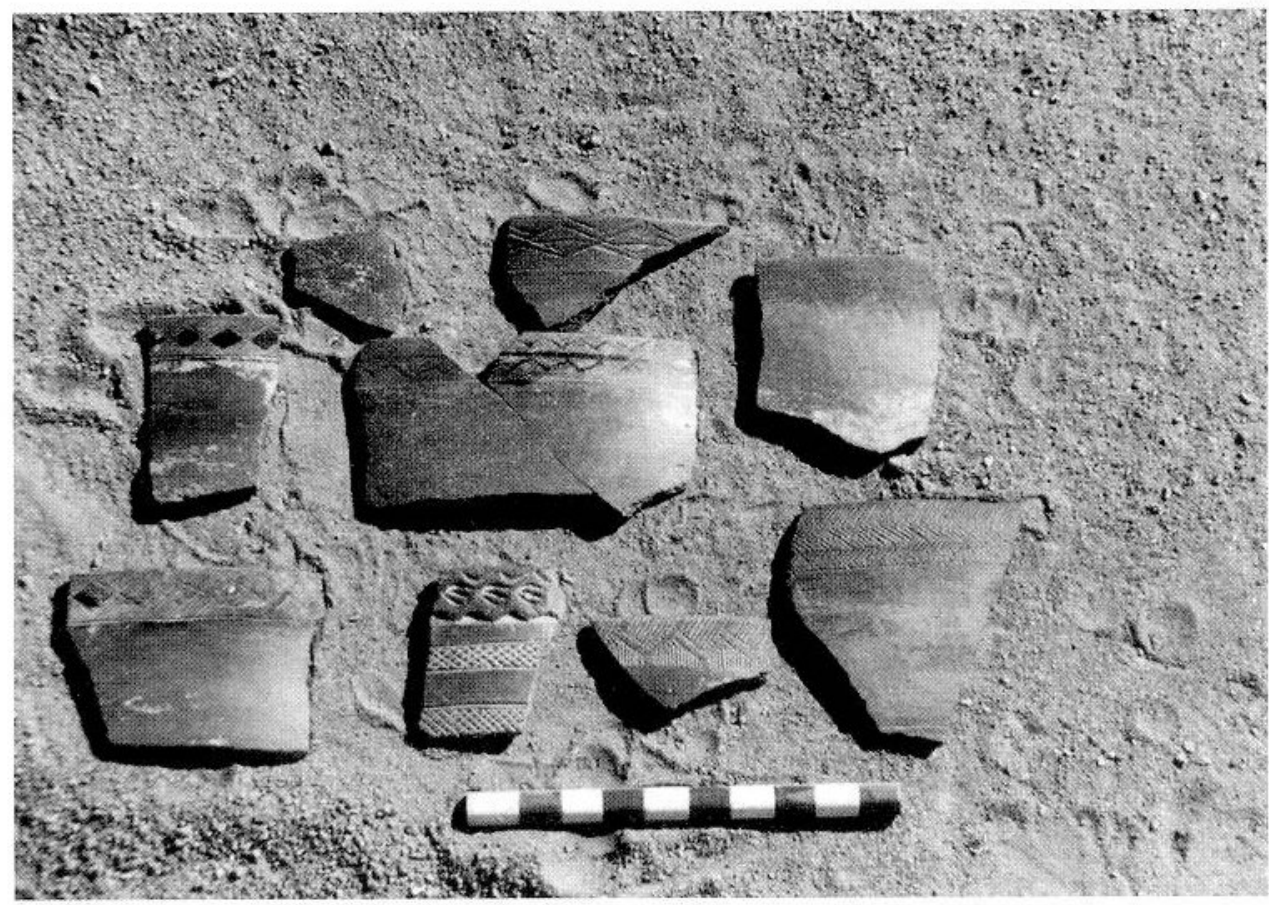

Figure 9c. Kerma pottery collected during the survey.

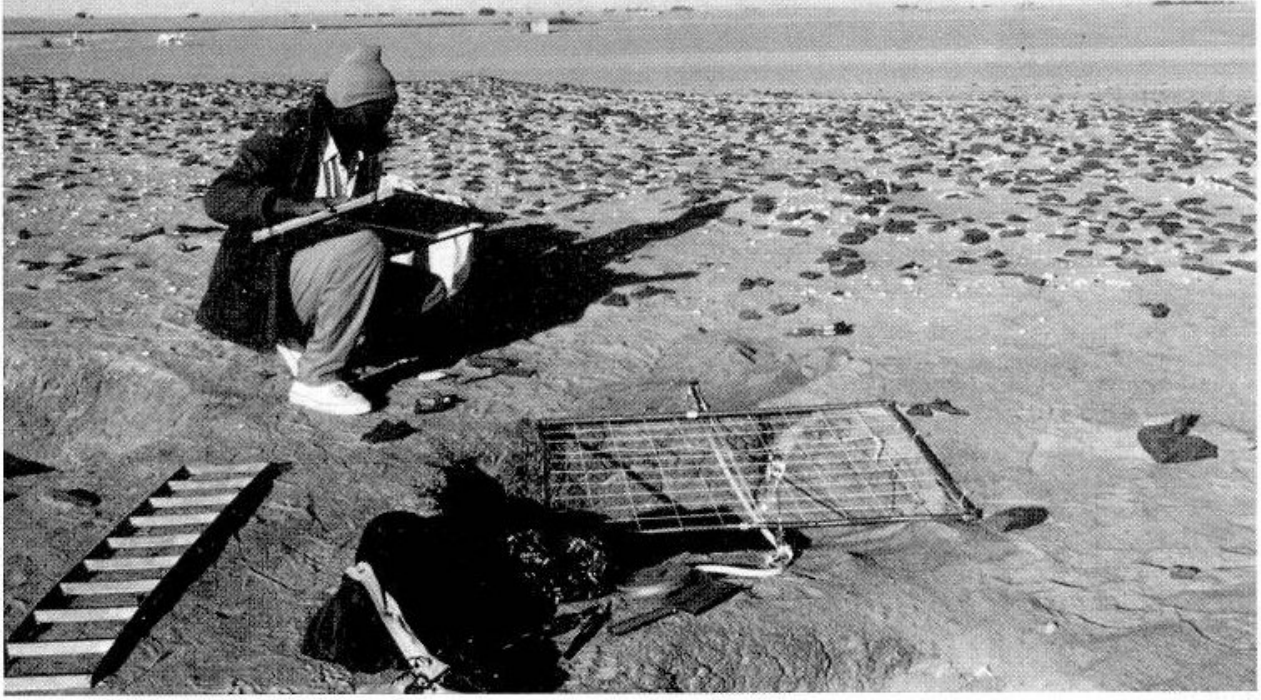

Figure 9d. Excavation of a Kerma cemetery in the Northern Dongola Reach. 


\section{ALLUVIAL SEDIMENTS AND LANDFORMS IN THE NORTHERN DONGOLA REACH}

\subsection{Fluvial Stratigraphy and Geomorphology}

Geomorphological fieldwork in the Northern Dongola Reach was undertaken during the 1995/1996 and 1996/1997 field seasons in order to provide geomorphological and palaeoenvironmental context for the changing pattern of settlement revealed by the archaeological survey data (Macklin \& Woodward, 1997, 1998). Agricultural development based on the exploitation of groundwater for irrigation is currently taking place in many parts of the archaeological survey concession. Large areas of the palaeochannel belts have been divided into small holdings of a few hectares and each is served by a series of groundwater pumps housed at the bottom of a pit. These square pits have been excavated into the alluvium to depths which typically range from 3 to $6 \mathrm{~m}$. They are normally 3 to $4 \mathrm{~m}$ across with straight, stable sides and they provide excellent 3D exposures in the alluvial sequence - occasionally down to Nubian sandstone bedrock (Fig. 10). These pits are present throughout the survey area and these exposures have provided most of our stratigraphical and sedimentological data.

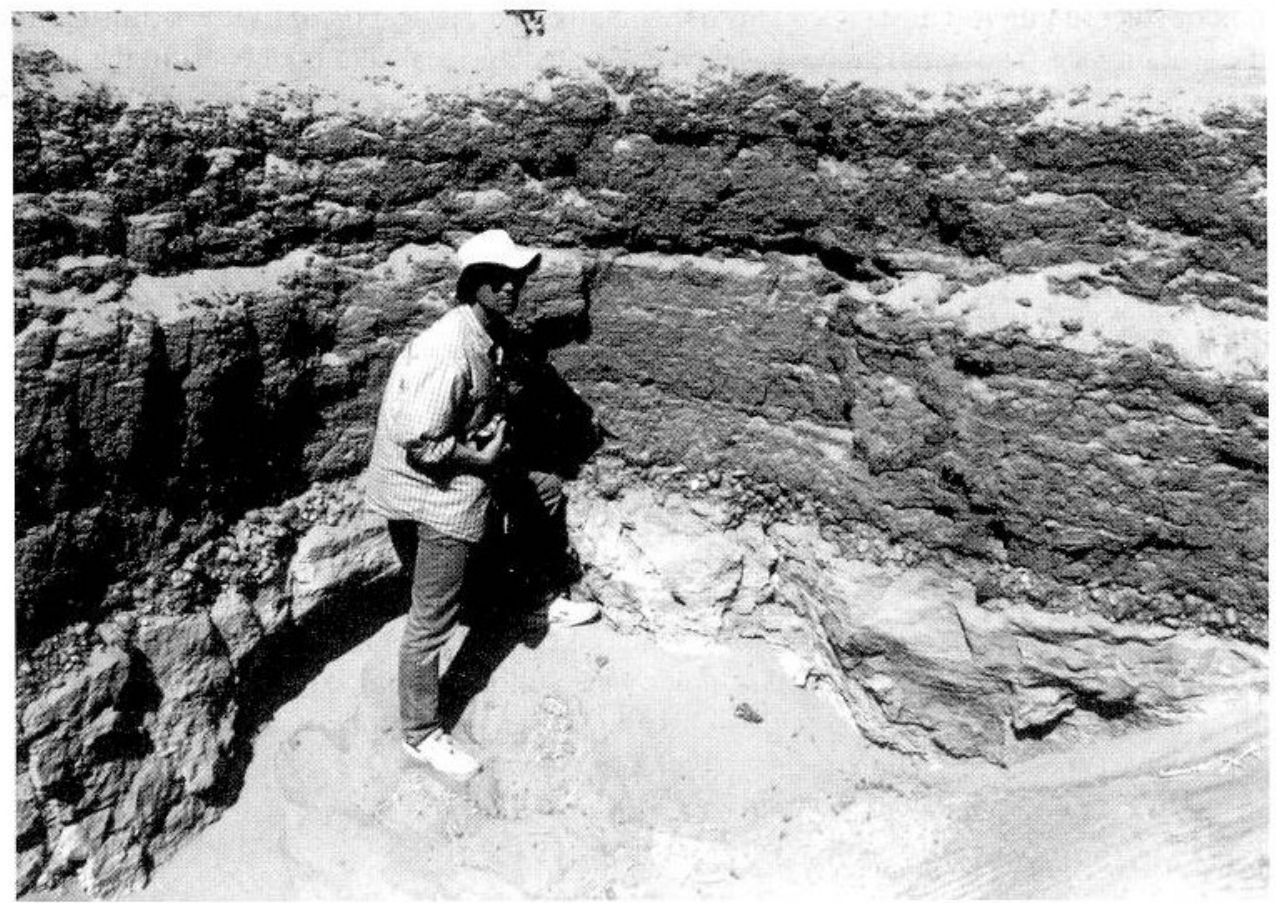

Figure 10. Holocene alluvial sediments and Nubian Sandstone bedrock exposed in a shallow (now disused) groundwater pump pit section in the Northern Dongola Reach. A thin (20 to $30 \mathrm{~cm}$ ) layer of sandy gravel overlies the bedrock. In general terms, the rest of the section comprises two massive units of silt with fine sand separated by a thin (c. 10 to $15 \mathrm{~cm}$ ) unit of well sorted fine sand at the same level as JCW's hat. The top of the sequence is covered by recent blown sand. 
The stratigraphic and sedimentological record has been recorded in detail at 31 pits and their locations are shown in Figure 11. They extend throughout the survey area stretching from Pit 29 on the eastern margin of the Seleim Basin in the north, to Pit 24 in the southern portion of the survey area near Barqat Kuluf less than $5 \mathrm{~km}$ from the modern Nile. Pits $4,7,8,9$ and 16 (and 12 and 13 in the south) are close to the bedrock plateau in the east of the survey area (Fig. 11) and demonstrate that the entire area is underlain by Nile alluvium which ranges in thickness from $<2 \mathrm{~m}$ to $>7 \mathrm{~m}$. Pits 5, 22, 26 and 27 are located within the Hawawiya Nile palaeochannel belt and Pits 1,2,18,19 and 29 are located within the Seleim Nile palaeochannel belt. Most of the other pits are located within or close to the Alfreda Nile palaeochannel belt (Fig. 11). The comparatively small number of pit sections on the Hawawiya palaeochannel belt is due to the presence of large dune systems in this part of the reach and less extensive agricultural development (see Plate 1).

\subsection{Geochronological Dating}

Optically stimulated luminescence (OSL) and radiocarbon techniques have been used to date the alluvial sediments and four of the dated sections are described below. Luminescence dating was carried out by Dr Mark Bateman at the University of Sheffield following the procedures outlined in Bateman \& Catt (1996). Samples were collected in the field from well sorted fine sand units (exposed in groundwater pump pits) by hammering a section of steel tubing $(4 \mathrm{~cm} \mathrm{ID} \times 20 \mathrm{~cm}$ ) horizontally into the section until it was flush with the section face. The sample tube was then excavated and sealed at both ends. In the laboratory all organics, carbonates and all minerals except quartz were removed from the sediment samples. Dosimetry was undertaken by ICP analysis of the elemental concentrations of uranium, thorium and potassium. Dose rates were attenuated for the grain sizes used $(90-125 \mu \mathrm{m})$ and for a palaeomoisture level based on the present with $5 \%$ errors. Sample analysis followed a multiple aliquot additive dose protocol (MAAD) with stimulation using a 75w Halogen lamp filtered with a GG420 filter and OSL signal monitored through a U-340 filter (Bateman \& Catt, 1996). All measurements were undertaken in a Riso automated luminescence reader. Inter-aliquot scatter was normalised using the total equivalent dose procedure. All the Northern Dongola Reach samples generated consistent results, growing linearly with dose with very low inter-aliquot scatter. The resultant palaeodose estimates (ED) could therefore be determined with confidence and a good level of precision (Mark Bateman, personal communication). We believe that the very effective zeroing of these sediments prior to burial by later flood sediments may be partly due to aeolian reworking during the dry season. Material suitable for radiocarbon dating was extremely rare; however, two charcoal samples were collected from exposures in Pits 12 and 26 . These were both associated with archaeological features (pottery and burnt earth, respectively) exposed in section.

\subsection{Seleim Nile Palaeochannel Belt}

\subsubsection{Pit 18 (N19 $07^{\prime} 26.0^{\prime \prime}$ E30 33 '09.5')}

This pit lies close to the southern edge of the Seleim Basin approximately $7 \mathrm{~km}$ due east of the modern Nile (Fig. 11). This site is located on the right bank of the Seleim Nile palaeochannel system about $4 \mathrm{~km}$ downstream of the confluence of the Alfreda and Hawawiya 


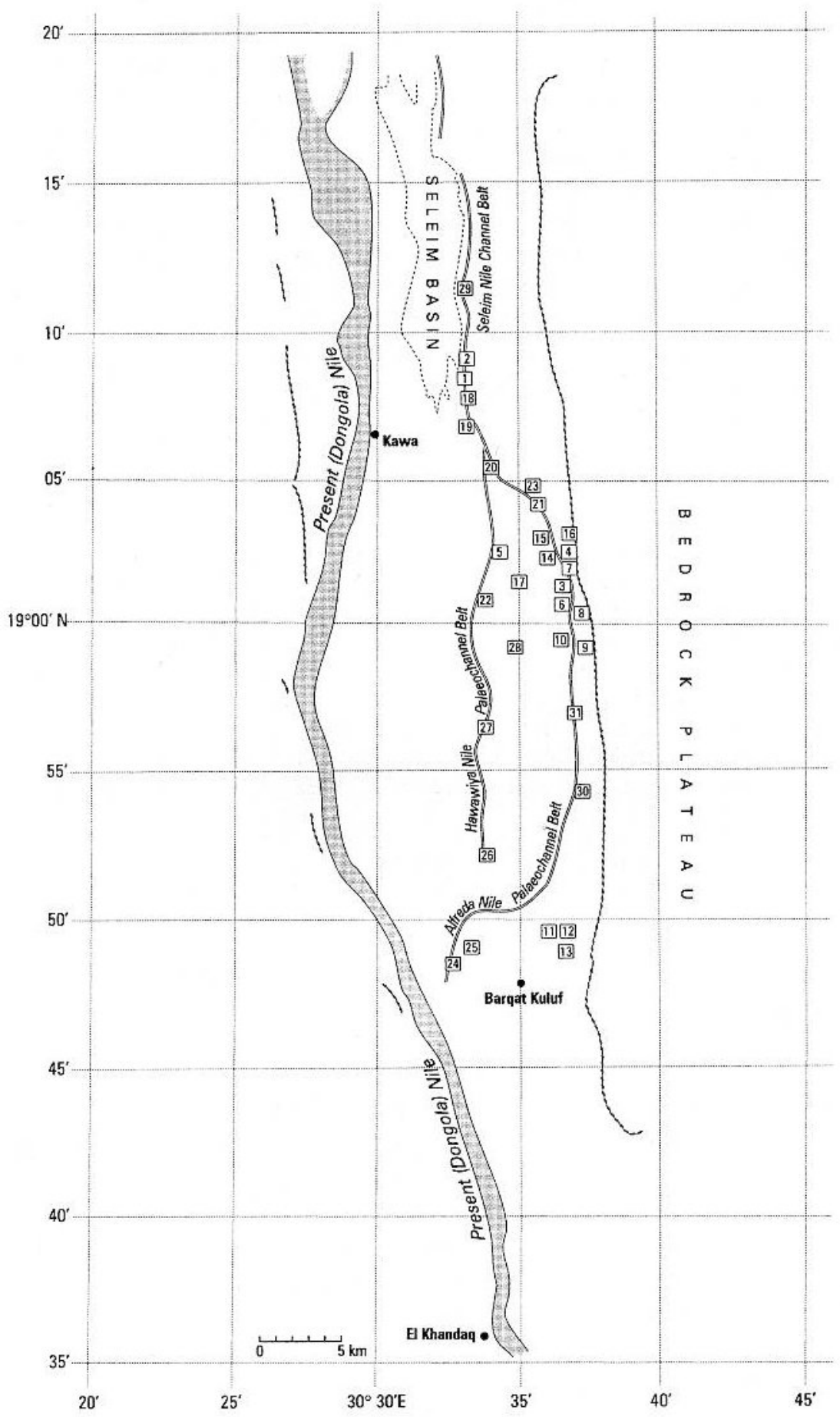

Figure 11. The distribution of groundwater pump pits selected for detailed study where the alluvial sequences have been logged. The major palaeochannel belts in the Northem Dongola Reach and the bedrock plateau marking the eastern extent of the survey area are also shown. Compare to SPOT image. 
346 Jamie C. Woodward et al.

palaeochannel belts (Welsby, 1995). This pit evidenced the second longest sequence recorded in the survey area with a maximum depth of $6.10 \mathrm{~m}$. Sandstone bedrock is exposed at the base of this pit and is overlain by $20 \mathrm{~cm}$ of well-rounded fluvial gravels that fine upwards to coarse sand (Fig. 12). The rest of the sequence comprises over $5 \mathrm{~m}$ of well sorted fine sand alternating with units of fine sandy silt. In common with many of the other sections, these silt units have low dip angles and represent lateral accretion at channel margins. Identical features can be observed at the margin of the present Nile. The prominent fine sand units exposed in Pit 18 ranged in thickness from c. 5 to $30 \mathrm{~cm}$. These materials have proved to be ideal for OSL dating. Sample depths and ages are shown on Table 2 and Figure 12 and these demonstrate that much of the alluvial sequence at this site within the Seleim Nile Palaeochannel belt dates from the beginning of the Early Kerma Period until sometime in the early part of the 1 st millennium BC, more than 700 years after the end of the Final Kerma Culture (Table 2).

Table 2. The OSL and radiocarbon dates from samples taken from pit sections in the Northern Dongola Reach. See Figure 11 for pit locations and palaeochannel belts. Sample depths from the top of the logged section (modern land surface) are also given. *Note that the date from Pit 26 is a radiocarbon date (BM-3128) that has been calibrated using the curve of Pearson \& Stuiver (1986) and the OxCal v2.18 calibration program. This figure gives a $68 \%$ probability that the true calendar date is between 2460 and 2420 or 2400 and 2270 or 2250 and $2200 \mathrm{BC}$ and a $95 \%$ probability that it is between 2460 and 2190 or 2170 and 2140 BC (Janet Ambers, personal communication, 1998). This sample dates to the Early Kerma Period (Table 1). **The date from Pit 12 is also a radiocarbon date on charcoal (Beta 100605). The calibrated age represents a 2 sigma uncertainty and dates to the Neolithic Period.

Pit No. Depth OSL or ${ }^{14} \mathrm{C}$ Age $\quad$ Calendar Age Culture (see Table 1)

Seleim Palaeochannel Belt:

18

18

$1.45 \mathrm{~m}$

$5.15 \mathrm{~m}$

Alfreda Palaeochannel Belt:
$1.30 \mathrm{~m}$

$0.75 \mathrm{~m}$

14

7

24

12

4

Hawawiya Palaeochannel Belt:
$4.40 \mathrm{~m}$

$1.60 \mathrm{~m}$

$1.55 \mathrm{~m}$

$1.83 \mathrm{~m}$

$2.55 \mathrm{~m}$
$1.2 \mathrm{~m}$

$2.30 \mathrm{~m}$
$2790 \pm 100 \mathrm{BP}$

$4500 \pm 300 \mathrm{BP}$
$790 \mathrm{BC}$

$2500 \mathrm{BC}$
Kushite

Pre/Early Kerma

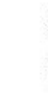

$\begin{array}{ll}1490 \pm 100 \mathrm{BP} & \mathrm{AD} 510 \\ 3190 \pm 300 \mathrm{BP} & 1190 \mathrm{BC} \\ 4060 \pm 300 \mathrm{BP} & 2060 \mathrm{BC} \\ 5170 \pm 530 \mathrm{BP} & 3170 \mathrm{BC} \\ 5680 \pm 300 \mathrm{BP} & 3680 \mathrm{BC} \\ 5100 \pm 80 \mathrm{BP} * * & 4045 \text { to } 3705 \mathrm{BC} \\ 7060 \pm 430 \mathrm{BP} & 5060 \mathrm{BC}\end{array}$

$1490 \pm 100 \mathrm{BP}$

Post-Meroitic

New Kingdom/Kushite

Early/Middle Kerma

Pre Kerma

Neolithic/Pre Kerma

Neolithic

Neolithic
26

(n)

$3830 \pm 50$ BP*

$7100 \pm 1090 \mathrm{BP}$

$7490 \pm 1120 \mathrm{BP}$
2460 to $2140 \mathrm{BC}$

$5100 \mathrm{BC}$

$5490 \mathrm{BC}$
Early Kerma

Neolithic

Neolithic 
Pit 18

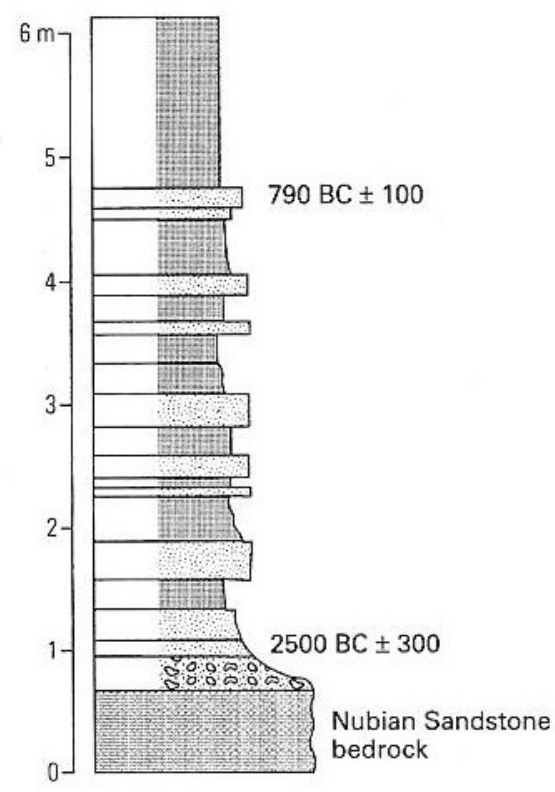

Pit 5
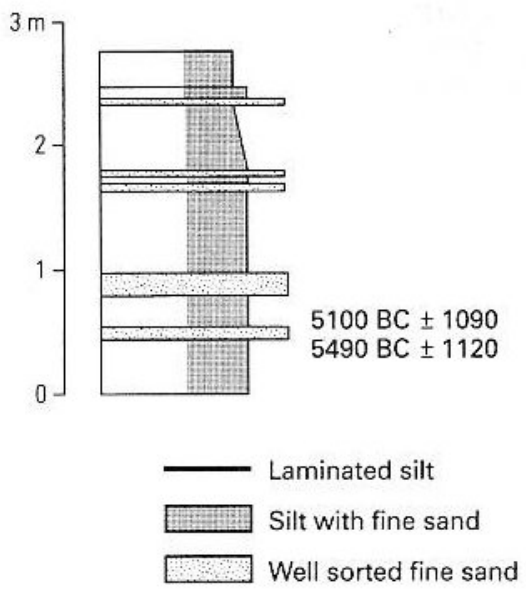

Pit 14

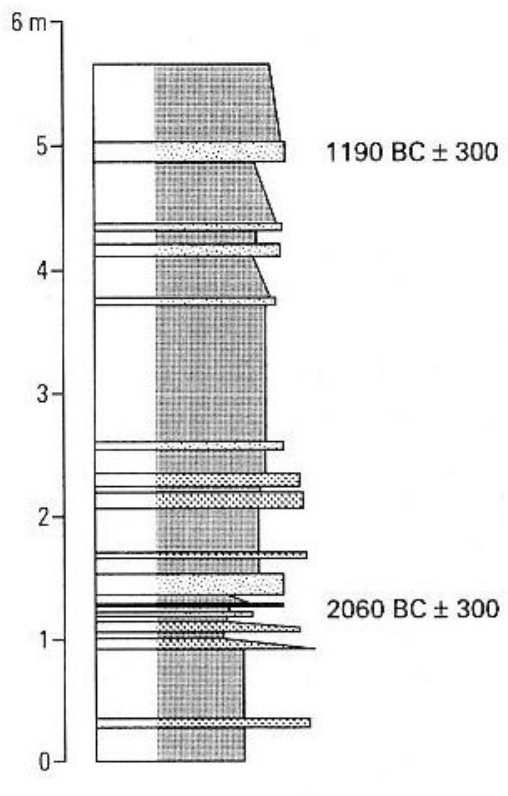

Pit 23

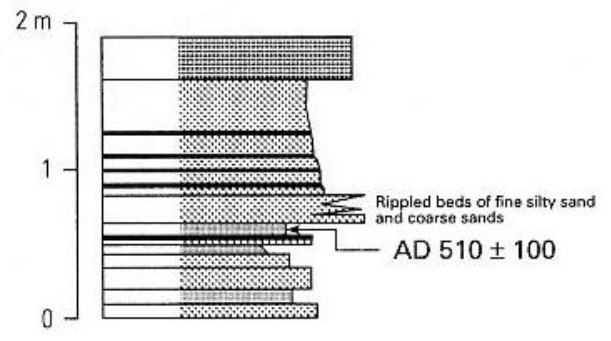

Figure 12. Schematic stratigraphic logs and OSL dates for selected pit sections within the main palaeochannel belts (see text for discussion). 


\subsection{Alfreda Nile Palaeochannel Belt}

\subsubsection{Pit 14 (N19 $02^{\circ} 31.4^{\prime \prime}$ E30 $\left.36^{\prime} 16.5^{\prime \prime}\right)$ :}

Pit 14 is located approximately $3.5 \mathrm{~km}$ from the bedrock plateau in the east of the survey area within the Alfreda Nile palaeochannel belt. This pit exposed a $5.70 \mathrm{~m}$ section of finegrained Holocene alluvial sediments. This sequence is similar to Pit 18 and comprises distinctive layers of well sorted fine sands that commonly grade upwards into fine sandy silts of varying thickness (Fig. 12). Two OSL dates have been obtained from this sequence (Table 2). The lower part of this sequence has been dated to an Early/Middle Kerma age of 2060 BC (Macklin \& Woodward, 1998). The upper part of this exposure (0.75 m from the modern land surface) has been dated to just after the Final Kerma Period with an age of $1190 \mathrm{BC}$. It is interesting to note that this pit is close to the isolated building at Site P4 that was excavated in 1996/1997 field season (Welsby, 1997) that may be of Classic Kerma age (1750-1580 BC). These OSL ages indicate that this channel belt was active throughout the Kerma Period (Table 2).

\subsubsection{Pit 23 ( N19 $04^{\circ} 38.0^{\prime \prime}$ E30 $\left.34^{\prime} 53.2^{\prime \prime}\right)$}

This is the only stratigraphic section shown on Figure 11 that was not obtained from an existing groundwater pit section. Pit 23 was dug into the bed of a well preserved palaeochannel in February 1997 with the aim of revealing sediments marking the last phase of fluvial activity in this channel. A $1.90 \mathrm{~m}$ section was exposed and the stratigraphy is shown in Figure 12. A sediment sample for OSL dating was collected from a depth of $1.30 \mathrm{~m}$ below the present land surface from the uppermost fluvial silty sand unit in this sequence. This yielded a date of $\mathrm{AD} 510$ (Table 2), which appears to be the last time there was significant flow in this channel. The transition from fluvial to aeolian facies was observed in section and the upper part of this sequence comprised $30 \mathrm{~cm}$ of well-rounded, medium to coarse grained aeolian sands (Figs 12 and 13). The colour and lithology of the aeolian sands at the top of this sequence is very similar to the material forming the active dunes and windblown sand sheets at the present land surface. It is interesting to note that recent data produced by the UK Natural Environment Research Council Tigger Project (Terrestrial Initiative in Global Environmental Research) have shown that a major shift to a more 'drought-ridden' regime occurred in the sub-Saharan Sahel at around the same time in the first millennium AD (Chaloner, 1997). This highlights the wider significance of the OSL and sedimentary data for the Northern Dongola Reach and the sensitivity of Nile flows to large-scale climatic fluctuations during the Holocene Period.

\subsection{Hawawiya Nile Palaeochannel Belt}

\subsubsection{Pit $5\left(\right.$ N1 $\left.^{\circ} 02.62^{\prime} E 30^{\circ} 33.94^{\prime}\right)$}

Pit 5 is the most northerly of the four sections we have logged and sampled on the Hawawiya palaeochannel complex and it is located approximately $6 \mathrm{~km}$ upstream of the main palaeochannel belt confluence with the Alfreda Nile (Fig. 11). The alluvial sediments exposed at this site reach a maximum depth of $2.8 \mathrm{~m}$ below the modern land surface (Fig. 12). Two OSL dates were obtained from a sample collected from a well sorted fine sand unit at a depth of $2.3 \mathrm{~m}$ and this gave ages of $5100 \mathrm{BC}$ and $5490 \mathrm{BC}$ (Table 2). Pit 5 is a comparatively shallow pit and the depth of the alluvial sequence in this part of the 


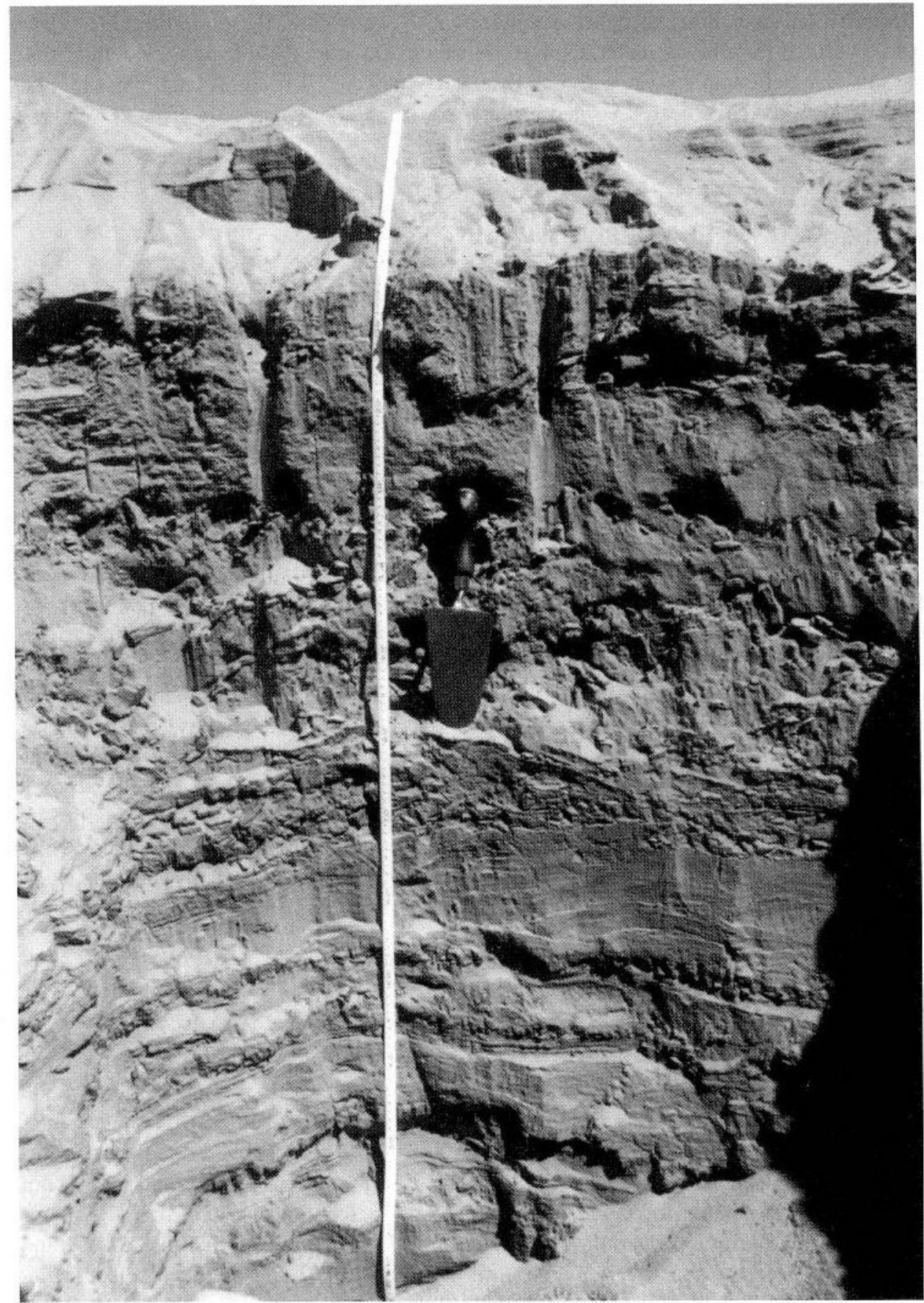

Figure 13. The sediments exposed in Pit 23. This section was excavated in February 1997 within t1 centre of the palaeochannel form shown in Figures 14 and 15. The sediments above the trowel a coarse-grained aeolian sands. Below the trowel the section comprises grey Nile silts interbeddt with fine- to medium-grained alluvial sands (see Fig. 12). 
Hawawiya palaeochannel complex is not known. Nevertheless, these are the oldest dates so far obtained for alluvial materials in the Northern Dongola Reach and they demonstrate that this channel complex was active in the early Holocene. It is significant that a number of Neolithic sites have been recorded in this part of the Hawawiya Nile (Fig. 8) (Welsby, 1995).

\section{PALAEOCHANNEL MORPHOLOGY AND PLANFORM}

At several locations in the Northern Dongola Reach the morphology of the Alfreda and Seleim Nile palaeochannel belts is well preserved at the present land surface. In contrast, the channels of the Hawawiya Nile are not so well preserved due to aeolian erosion (Welsby, 1995) and perhaps also their greater antiquity. Two extended transects have been surveyed across typical landform associations in the study area. Cross section 1 passed immediately to the north of Pit 14 (Fig. 11) across part of the Alfreda Nile palaeochannel belt. It covered a distance of $2.1 \mathrm{~km}$ extending westwards from the bedrock plateau that demarcates the eastern edge of the survey area. This transect includes a gently sloping alluvial fan complex (that drains from a small catchment in the bedrock plateau) as well as a prominent Kerma settlement mound (Site P5) (Fig. 9a). Approximately $50 \mathrm{~m}$ to the north of the settlement mound at P5, a well preserved Kerma building (Site P4) was excavated during the 1996/1997 field season (Fig. 9b). Around $700 \mathrm{~m}$ of low relief terrain lies between the Kerma settlement mound at P5 and the bedrock plateau forming a palaeochannel complex beginning at the base of the lower fan (Fig. 14). This feature is mantled by a thin veneer of very gently sloping blown sand which overlies fine-grained alluvial sediments.

The second transect covered a distance of almost $1.4 \mathrm{~km}$ and was surveyed across the palaeochannel feature where Pit 23 was excavated (Fig. 14). This channel has a relief of at least $2 \mathrm{~m}$ from channel bed to levée top and is approximately $140 \mathrm{~m}$ wide. This profile highlights the convex form of some of these alluvial systems with well developed levées bordered by low relief, inter-channel flood basins (Fig. 15) and it is likely that this channel was part of a larger system of anabranching channels (Macklin \& Woodward, 2001) (see Plate 1).

\section{DISCUSSION AND CONCLUSIONS}

The ten OSL and two radiocarbon dates reported here cover a time range of about 6000 years from the sixth millennium $\mathrm{BC}$ to the first millennium $\mathrm{AD}$ (Table 2). The Kerma Period spans only a small part of this period (2500 to $1500 \mathrm{BC}$, Table 1) and these dates show that the palaeochannel belts of the Northern Dongola Reach were regularly - if not permanently - inundated for much of the Holocene, before, during and after the major phase of Kerma Period occupation. The youngest OSL dates indicate that the Alfreda and Seleim Nile Palaeochannels were active until at least $800 \mathrm{BC}$ and, perhaps episodically, up to about AD 500 (Macklin \& Woodward, 1998).

During the 1994/1995 season, an almost uninterrupted spread of occupation material of Neolithic age was surveyed on either side of a 'wide depression' within the Hawawiya palaeochannel belt. The Kerma sites on the Hawawiya palaeochannel do not contain pottery 
The Holocene fluvial sedimentary record 351
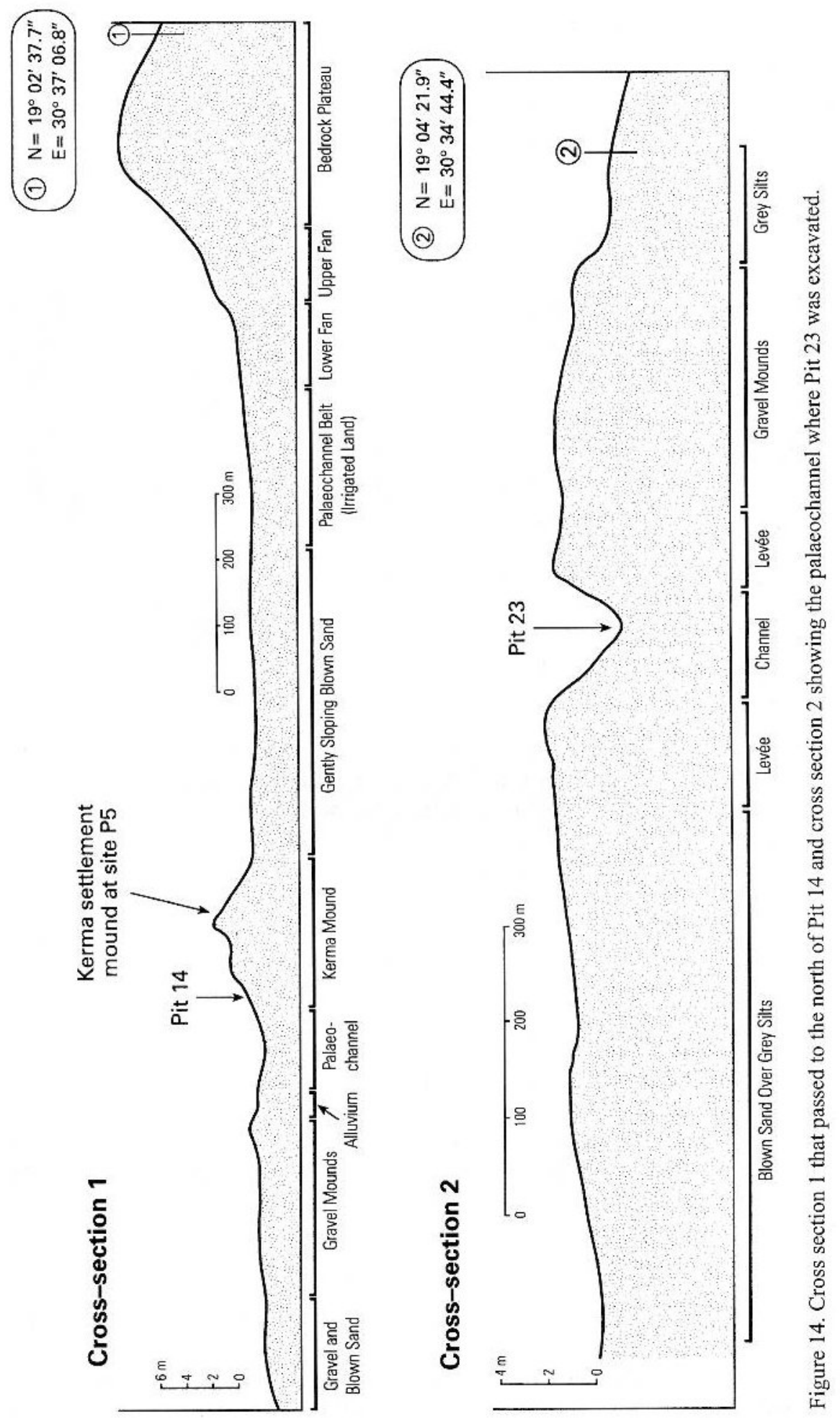
352 Jamie C. Woodward et al.

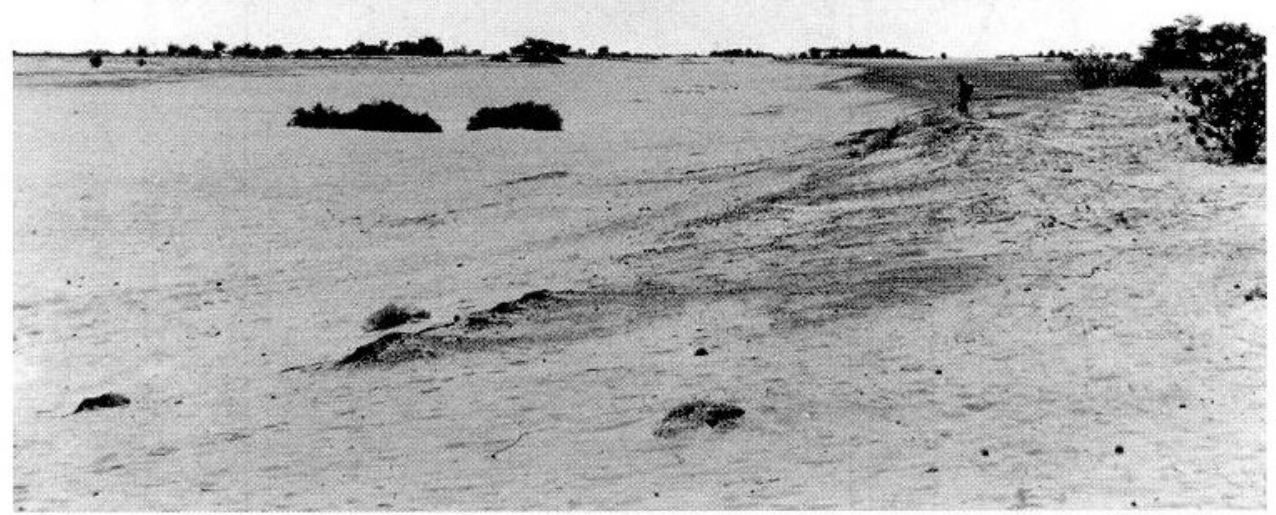

Figure 15. The palaeochannel and levée complex within cross section 2 shown in Figure 14.

later than the Classic Kerma Period (1750-1580 BC) suggesting that the Hawawiya Nile ceased to flow during or shortly after that period. In contrast, sites dating to later periods (Final Kerma, Kushite and Post-Meroitic, Table 1) are present on both the Alfreda and Seleim palaeochannel belts (Fig. 8). It is interesting to note that the dates from the two dated Pits (5 and 26) within the Hawawiya Nile are of Neolithic and Early Kerma age. The OSL dates from Pit 5 are the oldest so far obtained in the survey area and were from sediments at a depth of only $2.30 \mathrm{~m}$ below the present land surface. Seven of the dates listed in Table 2 are from six pits within the Alfreda Nile palaeochannel belt and these range from Neolithic $(5060 \mathrm{BC})$ to Post-Meroitic (AD 510) in age. The OSL dates from Pit 18 on the Seleim Nile range from Early/Pre-Kerma times $(2500 \mathrm{BC})$ to the Kushite Period $(790 \mathrm{BC})$ and demonstrate that the Alfreda and Seleim Niles conveyed floodwaters for at least two thousand years after the Kerma Period.

The pottery data from the Kerma sites demonstrate that the Hawawiya Nile palaeochannel belt ceased flowing before the end of the Classic Kerma Period. There is a reduction in settlement across the whole of the Northern Dongola Reach at this time with most of the later sites located close to the margins of the Alfreda and Seleim Niles (see Welsby, 1995). This pattern is in good agreement with the record of river activity based on the OSL and ${ }^{14} \mathrm{C}$ dates obtained to date (Macklin \& Woodward, 1997, 1998). It is not yet possible to comment upon changes in flood frequency and magnitude, but the presence of post-Kerma settlements, albeit in much smaller numbers, could suggest that the final demise of the Kerma culture in this part of the Nile Valley may not have been driven solely by climate change. It is possible, however, that a sequence of years with very low flows may have devastated much of the Kerma agriculture along the Alfreda and Seleim palaeochannel 
belts and, after the Kerma Period, available water resources were only sufficient to support a much smaller population. As Hassan (1998, p. 37) has stated:

Contrary to the traditional wisdom of Greek visitors in classical antiquity who consorted with priests rather than farmers, Nile floods are capricious. One in every five floods is harmful: over-flooding the fields, too low to irrigate the higher edge of the floodplain, unseasonably early or late, staying too long or falling too quickly. In addition, the dynamics of the river - changing its course, breaking levées, or over-silting basins - can change the fortunes of villages and homesteads.

Establishing the sequence and timing of palaeochannel abandonment in the Northern Dongola Reach is the first step in attempting to identify the cause of these cultural changes. At this point it is instructive to consider some of the previous work on the early and middle Holocene palaeochannels on the Gezira Plain in the lower reaches of the Blue Nile. Williams \& Adamson (1980) state that a major phase of Blue Nile incision may have started in the early Holocene, but its effects only became significant by middle Holocene times where former distributary channels that flowed across the Gezira Plain were beheaded and dried out - only transmitting flows during exceptional floods. This phase of incision seemed to coincide with a shift from a coarse- to fine-grained sediment load, and with an overall decline in flow volumes after the mid-Holocene as flood flows became concentrated in a single main channel (Williams \& Adamson, 1980). In the case of the palaeochannels of the Gezira Plain, Adamson et al. (1982, p. 187) have observed that:

'progressively less and less of the flood flow would be diverted into them [palaeochannels] as the main channel incised further and their own channels became lined with silt.'

It is interesting to compare this scenario with the sedimentary sequence recorded in Pit 23 on the youngest dated sediments of the Alfreda Nile palaeochannel where the thin bands of fluvial silt are finally replaced by coarse aeolian sands representing arid conditions (Fig. 12). The deposition of these silt units may represent exceptionally high flows from an incising Dongola Nile that periodically inundated the Alfreda Nile channels with shallow, silt-laden floodwaters. Subsequent channel flows were too low to inundate the palaeochannel belts and this process could have resulted from a decrease in flood magnitude as monsoon intensity waned in the first millennium $\mathrm{AD}$.

Further work is required in the Northern Dongola Reach to establish the altitudinal relationships between the major palaeochannel belts and the modern Dongola Nile. For example, long-term sediment deposition in the Hawawiya Nile may have elevated this channel belt above the surrounding flood basins, so that subsequent flows were conveyed by the Alfreda Nile to the east. These survey data will form an important part of any climatic, tectonic or other geomorphological explanation for the abandonment of the main palaeochannel belts and for the concentration of flood flows in the Dongola Nile. Detailed analysis and stratification of the Neolithic, Kerma and later pottery from across the survey area is still in progress and these chronological data will allow the relationship between river behaviour and human activity in the Northern Dongola Reach to be further refined. At the same time, it is interesting to note that several large palaeochannels within the Northern Dongola Reach identified on the SPOT satellite imagery are not associated with Kerma or later sites and further fieldwork is required to document the stratigraphy and establish the age of these features. 


\section{ACKNOWLEDGEMENTS}

MGM and JCW are grateful for the invitation to participate in the Northern Dongola Reach Survey and they thank the Sudan Archaeological Research Society of the British Museum for financial and logistical support. We thank Isabella Welsby Sjöström who has analysed the pottery from the NDRS and this work contributed to the development of Figure 8. We also thank David Appleyard and Lois Wright of the Graphics Unit in the School of Geography at Leeds for drawing the figures and John Dodds for assistance with image processing. We are also grateful to Dr Mark Bateman (University of Sheffield) who carried out the OSL analyses and the referees who provided helpful comments on this paper. This paper is dedicated to the memory of Kevin Jenkins who worked on this project for a few short weeks in the Autumn of 1997.

\section{REFERENCES}

Adams, W.Y. 1977. Nubia: Corridor to Africa. Allen Lane, London and Princeton.

Adamson, D.A., Gasse, F., Street, F.A. \& Williams, M.A.J. 1980. Late Quaternary History of the Nile. Nature, 288: 50-55.

Adamson, D.A., Williams, M.A.J. \& Gillespie, R. 1982. Palaeogeography of the Gezira and of the lower Blue and White Nile valleys. In: Williams, M.A.J. \& Adamson, D.A. (eds) A Land Between Two Niles: Quaternary Geology and Biology of the Central Sudan, Balkema, Rotterdam, 165-219.

Andah, K. \& Siccardi, F. 1991. Prediction of hydrometeorological extremes in the Sudanese Nile region: a need for international cooperation. In: Hydrology for the Water Management of Large River Basins, IAHS Publication No. 201: 3-12.

Bateman, M. D. \& Catt, J.A. 1986. An absolute chronology for the raised beach and associated deposits at Sewerby, East Yorkshire, England. Journal of Quaternary Science, 11: 389-395.

Bonnet, C. 1992. Excavations at the Nubian royal town of Kerma: 1975-91. Antiquity, 66: 611-625.

Butzer, K.W. 1980. Pleistocene History of the Nile Valley in Egypt and Lower Nubia. In: Williams, M.A.J. \& Faure, H. (eds) The Sahara and The Nile. Balkema, Rotterdam, 248-276.

Butzer, K.W. 1981. Long-term Nile flood variation and political discontinuities in Pharaonic Egypt. In: Clark, J.D. \& Brandt, S. (eds) The Causes and Consequences of Food Production in Africa. Berkeley, University of California Press,

Butzer, K.W. \& Hansen, C.L. 1968. Desert and River in Nubia: Geomorphology and Prehistoric Environments at the Aswan Reservoir. University of Wisconsin Press, Madison.

Chaloner, W. 1997. Global change: the time dimension. NERC News, Autumn 1997, 14-15.

Evans, T. 1994. History of Nile Flows. In: Howell, P.P. \& Allan, J.A. (eds) The Nile: Sharing a Scarce Resource. Cambridge University Press, Cambridge, 27-63.

Foucault, A. \& Stanley, D.J. 1989. Late Quaternary palaeoclimatic oscillations in East Africa recorded by heavy minerals in the Nile delta. Nature, 339: 44-46.

Gasse, F., Rognon, P. \& Street, F.A. 1980. Quaternary history of the Afar and Ethiopian Rift Lakes. In: Williams, M.A.J. \& Faure, H. (eds) The Sahara and The Nile. Balkema, Rotterdam, 361-400.

Gasse, F. \& van Campo, E. 1994. Abrupt post-glacial climatic events in West Asia and North Africa monsoon domains. Earth and Planetary Science Reviews, 1256: 435-456.

Hassan, F.A. 1981. Historical Nile Floods and their implications for climatic change. Science, 212: $1142-1145$.

Hassan, F.A. 1996. Abrupt Holocene climatic events in Africa. In: Pwiti, G. \& Soper, R. (eds) Aspects of African Archaeology, Papers from the 10th Congress of the PanAfrican Association for Prehistory and Related Studies, University of Zimbabwe Publications, Harare, 83-89. 
Hassan, F.A. 1997. The dynamics of a riverine civilization: a geoarchaeological perspective on the Nile Valley, Egypt. World Archaeology, 29: 51-74.

Hassan, F.A. 1998. Climatic change, Nile floods and civilization. Nature and Resources, 34: 34-40.

Hulme, M. 1994. Global climate change and the Nile basin. In: Howell, P.P. \& Allan, J.A. (eds) The Nile: Sharing a Scarce Resource. Cambridge University Press, Cambridge, 139-162.

Hulme, M.A. 1994. Global climate change and the Nile basin. In: Howell, P.P. \& Allan, J.A. (eds)

The Nile: Sharing a Scarce Resource. Cambridge University Press, Cambridge, 139-162.

Hurst, H.E. 1952. The Nile: A general account of the river and the utilization of its waters. London, Constable (Second Edition).

Macklin, M.G. \& Woodward, J.C. 1997. Holocene Alluvial History in the Northern Dongola Reach of the Nile: the 1996/1997 field season. Sudan and Nubia, 1: 13-15.

Macklin, M.G. \& Woodward, J.C. 1998. Alluvial architecture and luminescence dating of Holocene palaeochannels in the Northern Dongola Reach of the Nile. Sudan and Nubia, 2: 21-25.

Macklin, M.G. \& Woodward, J.C. 2001. Holocene alluvial history and the palaeochannels of the Northern Dongola Reach of the Nile: A preliminary report. In: Welsby, D.A. (ed.) Survey and Excavation in The Northern Dongola Reach. SARS Monograph (in press).

Milliman \& Syvitski, J.P.M. 1992. Geomorphic/Tectonic control of sediment discharge to the ocean: the importance of small mountainous rivers. The Journal of Geology, 100: 525-544.

Pearson, G.W. \& Stuiver, M. 1986. High precision calibration of the radiocarbon time scale, 5002500 BC. Radiocarbon, 29: 839-861.

Phillipson, D.W. 1993. African Archaeology. Cambridge University Press, Cambridge.

Richards, K.S., Chandra, S. \& Friend, P. 1993. Avulsive channel systems: characteristics and examples. In: Best, J.L. \& Bristow, C.S. (eds) Braided Rivers, Geological Society Special Publication, No.75: 195-203.

Ritchie, J.C., Eyles, C.H. \& Haynes, C.V. 1985. Sediment and pollen evidence for an early to midHolocene humid period in the eastern Sahara. Nature, 314: 352-355.

Rossignol-Strick, M., Nesteroff, W., Olive, P. \& Vergnaud-Grazzini, C. 1982. After the Deluge: Mediterranean Stagnation and Sapropel Formation. Nature, 295: 105-110.

Said, R. 1993. The River Nile: Geology, Hydrology and Utilization, Pergamon Press, Oxford.

Said, R. 1994. Origin and Evolution of the Nile. In: Howell, P.P. \& Allan, J.A. (eds) The Nile: Sharing a Scarce Resource. Cambridge University Press, Cambridge, 17-26.

Street, F.A. \& Grove, A.T. 1979. Global maps of lake-level fluctuations since 30,000 years BP. Quaternary Research, 10: 83-118.

Street-Perrot, F.A., Marchand, D.S., Roberts, C.N. \& Harrison, S.P. 1989. Global Lake-Level Variations from 180,000 to 0 Years Ago: A Palaeoclimatic Analysis. US Department of Energy Technical Reports (TRO46), 1-213.

Welsby, D.A. 1995. The Northern Dongola Reach Survey, the 1994/95 season. a: The Survey. SARS Newsletter, 8: 2-7.

Welsby, D.A. 1997. The Northern Dongola Reach Survey, the 1996/97 season: Excavation at Sites O16, P1, P4 and P37. Sudan and Nubia, 1: 2-10.

Welsby D.A. 1998. Survey and excavation at Kawa, the 1997/98 season. Sudan and Nubia, 2: 15-20.

Wendorf, F. \& Schild, R. 1976. Prehistory of the Nile Valley. New York, Academic Press.

Williams, M.A.J. \& Adamson, D.A. 1980. Late Quaternary depositional history of the Blue and White Nile rivers in central Sudan. In: Williams, M.A.J. \& Faure, H. (eds) The Sahara and the Nile: Quaternary Environments and Prehistoric Occupation in Northern Africa, Balkema, Rotterdam, 281-304.

Williams, M.A.J. \& Adamson, D.A. 1982. (eds) A Land Between Two Niles: Quaternary Geology and Biology of the Central Sudan, Balkema, Rotterdam.

Williams, M.A.J., Dunkerley, D.L., De Deckker, P., Kershaw, A.P. \& Chappell, J. 1998. Quaternary Environments. 2nd ed., Arnold, London. 